\title{
Pelagic primary production in the coastal Mediterranean Sea: variability, trends, and contribution to basin-scale budgets
}

\author{
Paula Maria Salgado-Hernanz ${ }^{1,2}$, Aurore Regaudie-de-Gioux ${ }^{3}$, David Antoine ${ }^{4,5}$, and Gotzon Basterretxea ${ }^{1}$ \\ ${ }^{1}$ Department of Marine Ecology, IMEDEA (UIB-CSIC), Miquel Marquès 21, 07190 Esporles, Spain \\ ${ }^{2}$ Centro Oceanográfico de Baleares, Instituto Español Oceanografía (COB - IEO), Muelle de Poniente s/n, \\ 07015 Palma de Mallorca, Spain \\ ${ }^{3}$ ODE/DYNECO/Pelagos, Centre de Bretagne, IFREMER, I. Technopôle Brest-Iroise, \\ Pointe du Diable BP70 29280 Plouzané, France \\ ${ }^{4}$ Remote Sensing and Satellite Research Group, School of Earth and Planetary Sciences, \\ Curtin University, Perth, WA 6845, Australia \\ ${ }^{5}$ Sorbonne Université, CNRS, Laboratoire d'Océanographie de Villefranche, LOV, 06230 Villefranche-sur-Mer, France
}

Correspondence: Paula Maria Salgado-Hernanz (pmsalgadohernanz@gmail.com) and Gotzon Basterretxea (gotzon@imedea.uib-csic.es)

Received: 4 December 2020 - Discussion started: 11 January 2021

Revised: 18 May 2021 - Accepted: 10 July 2021 - Published: 3 January 2022

\begin{abstract}
We estimated pelagic primary production (PP) in the coastal $(<200 \mathrm{~m}$ depth) Mediterranean Sea from satellite-borne data, its contribution to basin-scale carbon fixation, its variability, and long-term trends during the period 2002-2016. Annual coastal PP was estimated at $0.041 \mathrm{Gt} \mathrm{C}$, which approximately represents $12 \%$ of total carbon fixation in the Mediterranean Sea. About $51 \%$ of this production occurs in the eastern basin, whereas the western and Adriatic shelves contribute with $\sim 25 \%$ each of total coastal production. Strong regional variability is revealed in coastal $\mathrm{PP}$, from high-production areas $\left(>300 \mathrm{~g} \mathrm{C} \mathrm{m}^{-2}\right)$ associated with major river discharges to less productive provinces $(<$ $50 \mathrm{~g} \mathrm{C} \mathrm{m}^{-2}$ ) located in the southeastern Mediterranean. PP variability in the Mediterranean Sea is dominated by interannual variations, but a notable basin-scale decline $(17 \%)$ has been observed since 2012 concurring with a period of increasing sea surface temperatures in the Mediterranean Sea and positive North Atlantic Oscillation and Mediterranean Oscillation climate indices. Long-term trends in PP reveal slight declines in most coastal areas $\left(-0.05\right.$ to $-0.1 \mathrm{~g} \mathrm{Cm}^{-2}$ per decade) except in the Adriatic where PP increases at $+0.1 \mathrm{~g} \mathrm{C} \mathrm{m}^{-2}$ per decade. Regionalization of coastal waters based on PP seasonal patterns reveals the importance of river effluents in determining PP in coastal waters that can regionally increase up to 5-fold. Our study provides insight into the
\end{abstract}

contribution of coastal waters to basin-scale carbon balances in the Mediterranean Sea while highlighting the importance of the different temporal and spatial scales of variability.

\section{Introduction}

Coastal ocean waters (i.e., < $200 \mathrm{~m}$ depth) are an important link between the land and the open ocean. They act as a buffer between terrestrial and human influences and the open ocean (Liu et al., 2000). Despite their relatively reduced extension ( $\sim 7 \%$ of ocean surface area; Gattuso et al., 1998), they behold some of the most productive habitats on the planet. Therefore, they have a disproportionate importance in many basin-scale biogeochemical and ecological processes, including carbon and nitrogen cycling, and in the maintenance of marine diversity (Cebrian, 2002; Coll et al., 2010; Dunne et al., 2007). Besides, biological production of continental shelves supports over $90 \%$ of global fish catches (Pauly et al., 2002; Pauly and Christensen, 1995).

Coastal seawaters support high primary production (PP), contributing to some $10 \%$ of global ocean PP and up to $30 \%$ if estuarine and benthic production is considered (Ducklow et al., 2001; Muller-Karger et al., 2005). These high rates of organic productivity occur in the coastal oceans due to the 
rapid turnover of the large inputs of nutrients and organic carbon from land. PP drives a significant carbon sink in the ocean (Field et al., 1998; Laws et al., 2000) and is a key regulator of ecological processes such as elemental cycling, trophic structure variabilities, and climate change (Bauer et al., 2013; Chavez et al., 2011). In coastal waters, physical and biological processes enhance the carbon transport out of the continental margins into the deep layers of the oceans, thus connecting terrestrial with deep oceanic systems (Cai, 2011; Carlson et al., 2001; Cole et al., 2007). The productivity of coastal sea areas is also of strategic socio-economic importance for many countries considering that PP constrains the amount of fish and invertebrates available to expanding fisheries, a primary resource for many coastal human communities (Chassot et al., 2010). The estimation and understanding of PP evolution and trends in the coastal seas is therefore essential to improve our knowledge of the oceanic carbon cycle.

Scaling up local measurements to estimate the contribution of coastal regions to global carbon fluxes has been hindered by the high spatial and temporal heterogeneity of these waters. Global models of oceanic systems produce carbon fixation estimates with a high degree of uncertainty in coastal regions (Muller-Karger et al., 2005). Coastal waters are complex because of the tight connection between terrestrial and oceanic systems. Terrestrial uploads of nutrients and organic matter originating from groundwater discharges, flash floods, or river runoff as well as exchanges with the seafloor strongly control the productivity of these waters (Basterretxea et al., 2010; Woodson and Litvin, 2014). The amplitude of seasonal variation in surface chlorophyll (chl) and surface temperature is often higher in coastal waters compared to the open ocean (Cloern and Jassby, 2008). Furthermore, coastal topography and its interaction with winds, waves, and currents generates a high variety of physicochemical niches for phytoplankton growth. Likewise, benthic-pelagic coupling allows the remineralization of nutrients present in shelf sediments during most intense storms. These episodic variations may constitute an important contribution to the overall productivity of shelf waters. Because of the high spatiotemporal heterogeneity in the main coastal subsystems and the concomitant lack of data, most estimated carbon fluxes in these subsystems have relatively high uncertainties (Bauer et al., 2013). In addition, direct human activities and climate change lead to a long-term variation in terrestrial fluxes and coastal biogeochemistry that can potentially have important consequences for the global carbon cycle (Gregg et al., 2003).

In the Mediterranean Sea, coastal and shelf areas represent about $21 \%$ of the global basin $\left(259000 \mathrm{~km}^{2}\right)$, which is a higher contribution than for the global ocean (Pinardi et al., 2006). Although the Mediterranean Sea is included amongst the most oligotrophic areas of the world oceans, it can display marked spatial productivity variations related to the variety of regional climate and oceanographic conditions as well as related to the multiple land-derived fluxes that locally fertilize the coastal waters (Goffart et al., 2002). Nutrientrich effluents from human activities on the coast (domestic wastewater, fertilizers, industry, etc.) and natural river discharges affect continental shelf productivity in this sea, sustaining locally enhanced pelagic and benthic biomass. Nevertheless, the influence of some river flows has been notably reduced by damming affecting water chemistry and sediment loads and, thereby, the productivity of coastal waters at local and regional scales (Ludwig et al., 2009; Tovar-Sánchez et al., 2016). Moreover, intensive agricultural practices and urbanization have brought unprecedented use and contamination of coastal groundwater (Basterretxea et al., 2010; TovarSánchez et al., 2014). For example, the use of fertilizers has resulted in higher nutrient flow into the Adriatic and in the lagoons of the Nile River, which has led to eutrophication (Turley, 1999). However, the impact of this anthropogenic nutrient enrichment may vary between regions, and modeling projections suggest spatial variations in PP as a result of climate change.

Accurate quantification of the coastal PP is fundamental for assessment of global carbon cycling in the Mediterranean Sea. Changes in PP have important effects on fish stocks that are socially relevant because of the economical dependency of many Mediterranean coastal communities on marine food products. Several studies have assessed PP at the scale of the entire Mediterranean Sea from satellite remote sensing data (Bosc et al., 2004; Bricaud et al., 2002; Lazzari et al., 2012). However, coastal areas were generally ignored in such studies, so that their contribution to basin-scale budgets is still largely unknown. Most coastal studies have a focus on specific regions and/or times (Estrada, 1996; Marty et al., 2002; Moutin and Raimbault, 2002; Rahav et al., 2013). Observed rates of climate change in the Mediterranean basin exceed global trends (Cramer et al., 2018) and future warming in the Mediterranean region is expected to be above global rates by $25 \%$ (Lionello and Scarascia, 2018). Long-term responses of $\mathrm{PP}$ in coastal areas to climate forcing remain uncertain however because of the scarcity of adequate field datasets (Gasol et al., 2016).

In this study, we present major characteristics of pelagic PP in Mediterranean coastal waters based on satellite-borne observations for the period 2002-2016. First, we provide global estimations of PP in coastal waters, and we assess their contribution to basin-scale PP, their interannual variability, and long-term trends. Then, we regionalize the coastal waters based on their temporal patterns of pelagic PP using self-organizing maps (SOMs), and we analyze the contribution of each region to total coastal PP. 


\section{Materials and methods}

\subsection{Remote sensing data}

We used the Mediterranean Sea Level-3 reprocessed surface chlorophyll concentration product (Chl L3) obtained from the EU Copernicus Marine Environment Monitoring Service (CMEMS). This product merges multi-satellite observations, and it is available at $1 \mathrm{~d}$ and $1 \mathrm{~km}$ resolution (https://resources.marine.copernicus.eu/ product-detail/OCEANCOLOUR_MED_CHL_L3_REP_ OBSERVATIONS_009_073/, last access: 2 August 2019). Specifically, the dataset used is "dataset-oc-med-chl-multi13-chl_1km_daily-rep-v02", and the variable name used is "mass_concentration_of_chlorophyll_a_in_sea_water (Chl)" obtainable in a NetCDF-4 file format. This Chl L3 dataset is derived with an updated version of the regional algorithm MedOC4 (Mediterranean Ocean-Colour 4 bands MedOC4; Volpe et al., 2019) for deep pelagic Case-1 waters and the AD4 algorithm (ADriatic 4 band; Berthon and Zibordi, 2004; D'Alimonte and Zibordi, 2003) for Case-2 coastal waters (generally shallow and turbid waters).

Level-2 sea surface temperature $\left(\mathrm{SST},{ }^{\circ} \mathrm{C}\right)$ at $1 \mathrm{~d}$ and $1 \mathrm{~km}$ was obtained from every available orbit from the Moderate Resolution Imaging Spectroradiometer (MODIS) aboard the Terra and Aqua satellites. Data were downloaded from the National Aeronautics and Space Administration (NASA) archive website (http://oceancolor.gsfc.nasa.gov/, last access: 18 July 2017). Only nighttime orbits were selected to avoid problems with skin temperature during daylight. Orbits with quality flags 0 (best), 1 (good), and 2 (questionable) in SST were included after checking their validity and accuracy in order to have a more complete dataset. Daily ( $24 \mathrm{~h}$ averaged) photosynthetically active radiation (PAR, in $\mathrm{Em}^{-2}$ ) was obtained as a Level-3 product at $9 \mathrm{~km}$ and $1 \mathrm{~d}$ resolution. This is the best available resolution at the NASA archive of MODIS and Medium Resolution Imaging Spectrometer (MERIS) data (https://oceancolor.gsfc.nasa.gov/13/, last access: 30 December 2017).

All satellite-derived variables were remapped onto a regular $1 \mathrm{~km}$ spatial grid over the study area, by averaging all available pixels within each grid cell. For each parameter, outliers were removed whenever they exceeded 3 times the mean $\pm \mathrm{SD}$ (standard deviation) of the time series. For the purpose of this study, coastal areas were defined as the waters lying between 5 and $200 \mathrm{~m}$ depth. Only values at depths exceeding $5 \mathrm{~m}$ depth were considered in order to reduce the possible influence of seafloor vegetation reflectance in chlorophyll concentration values $\left(\mathrm{chl}, \mathrm{mg} \mathrm{m}^{-3}\right.$ ) at shallow waters. The analyzed time series covers the period from January 2002 to December 2016 for the Mediterranean Sea (30 to $46^{\circ} \mathrm{N}$ and $6^{\circ} \mathrm{W}$ to $37^{\circ} \mathrm{E}$, Fig. 1).

\subsection{Primary production estimates}

PP was estimated from satellite-derived chl, SST, and PAR values using the time, depth, and wavelength-resolved lightphotosynthesis model of Morel (1991). This model was previously used for estimating PP in the Mediterranean Sea (Antoine and André, 1995) and at global scale (Antoine et al., 1996; Antoine and Morel, 1996) and performs well when compared to in situ measurements (Campbell et al., 2002; Friedrichs et al., 2009) or when compared to other similar algorithms designed for use with satellite observations (Carr et al., 2006; Saba et al., 2011). Instantaneous production at depth $z(\mathrm{~m})$ of the water column, time $t$ of the day, and for absorption of irradiance at wavelength $\lambda, P(\lambda, z, t)$ is calculated as

$P(\lambda, z, t)=E(\lambda, z, t) \operatorname{chl}(z) a^{*}(\lambda, z) \Phi$

$\left(\mathrm{gC} \mathrm{m}^{-3} \mathrm{~s}^{-1}\right)$

where $E(\lambda, z, t)$ is the spectral scalar irradiance for wavelength $\lambda$, depth $z$, and time $t$ of the day (molphotons $\left.\mathrm{m}^{-2} \mathrm{~s}^{-1}\right) ; a^{*}(\lambda, z)$ is the spectral chlorophyllspecific absorption coefficient of phytoplankton $\left(\mathrm{m}^{2} \mathrm{mg} \mathrm{chl}^{-1}\right)$; and $\Phi$ is the quantum yield of photosynthesis for carbon fixation $(\mathrm{molCmol}$ per photon; its possible spectral changes are ignored). Note that chl, $a^{*}$, and $\Phi$ are not made variable with time.

The triple integration of (1) with respect to wavelength, depth, and time gives the daily column-integrated primary production, PP:

daily $\mathrm{PP}=12 \int_{0}^{D} \int_{0}^{\min \left(Z_{\mathrm{p}} / Z_{\mathrm{b}}\right)} \int_{400}^{700} \mathrm{P}(\lambda, z, t) \mathrm{d} \lambda \mathrm{d} z \mathrm{~d} t$

$\left(\mathrm{g} \mathrm{Cm}^{-2}\right)$,

where the factor 12 is the conversion from moles to grams of carbon, $D$ is the day length or hours of daylight (h), $Z_{\mathrm{p}}(\mathrm{m})$ is the depth where the photosynthetically available radiation (PAR) falls to $0.1 \%$ of its value just below the sea surface (so approximately 1.5 times the euphotic depth), and $Z_{\mathrm{b}}$ is the bottom depth taken from the ETOPO1 database (Amante and Eakins, 2009). The time integration used intervals equal to $1 / 30$ of the day length (about 20 to 30 min depending on season). The depth integration used intervals equal to $1 / 50$ of $Z_{\mathrm{p}}$ and goes down to whichever is shallower between $Z_{\mathrm{p}}$ and $Z_{\mathrm{b}}$. The spectral integration is performed over the visible range ( 400 to $700 \mathrm{~nm}$ ) with a $5 \mathrm{~nm}$ resolution.

The spectral irradiance at a given depth $z, E(\lambda, z, t)$, is calculated as (starting from just below the sea surface)

$E(\lambda, z, t)=E(\lambda, z-\mathrm{d} z, t) e^{\left[-K_{\mathrm{d}}(\lambda, z) \mathrm{d} z\right]}$,

where the diffuse attenuation coefficient for downward irradiance, $K_{\mathrm{d}}(\lambda, z)\left(\mathrm{m}^{-1}\right)$, is computed as a function of chlorophyll following Morel and Maritorena (2001):

$K_{\mathrm{d}}(\lambda, z)=K_{\mathrm{W}}(\lambda, z)+\chi(\lambda) \operatorname{chl}(z)^{e(\lambda)}$. 


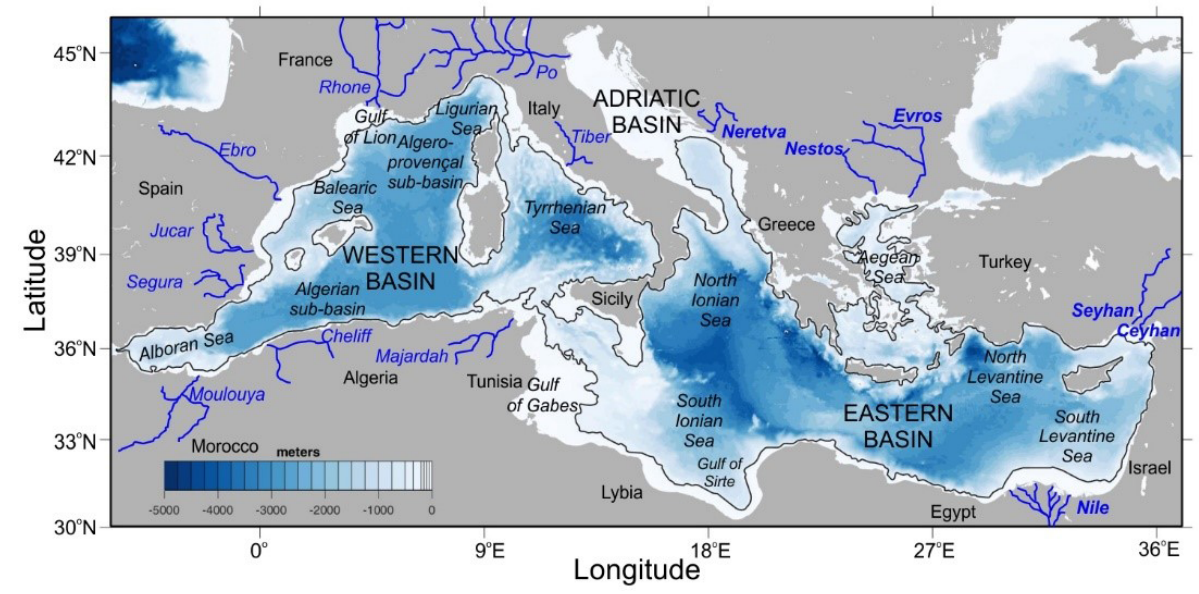

Figure 1. Map of the Mediterranean Sea showing the main basins, sea regions, surrounding countries and major rivers. Bathymetric data were obtained from ETOPO1 (Amante and Eakins, 2009). The black contour indicates the $200 \mathrm{~m}$ isobath, the limit of coastal waters as defined in the present study.

Details about how values are assigned to the parameters $a^{*}$ and $\Phi$, their dependence on temperature, and other features of this net primary production (NPP) model are to be found in Morel (1991) and Morel et al. (1996).

Daily PP calculation was performed every $7 \mathrm{~d}$ (starting at day 4), using the averaged chl for a $7 \mathrm{~d}$ window from day -3 to day +3 and for one grid point out of three. Therefore, the PP model was run with $8 \mathrm{~d}$ resolution and for one pixel out of three pixels. Later, daily PP data were interpolated to a $1 \mathrm{~d}$ by $1 \mathrm{~km}$ grid. Monthly PP data and their anomalies were derived from the abovementioned dataset.

The model was operated both for clear-sky conditions and for the actual MODIS PAR values, in which case a reduction of the clear-sky irradiance is uniformly applied across the entire day, as being the ratio of the daily satellite to clearsky PAR values. Chl is assumed to be uniformly distributed with depth and equal to the satellite-derived value. This simplification was considered more appropriate for the generally shallow and well-mixed waters of coastal areas than the use of global parameterization of the shape of the vertical profile as a function of the surface chl value (e.g., Morel and Berthon, 1989; Uitz et al., 2006), whose validity outside of open ocean waters is not established.

From PP estimates, new $\left(\mathrm{PP}_{\text {new }}\right)$ and regenerated $\left(\mathrm{PP}_{\text {reg }}\right)$ production were calculated using the ratio of export production $\left(\mathrm{PP}_{\mathrm{exp}}\right)$ to total production (PP) (i.e., ef-ratio) (Laws et al., 2000, 2011). Indeed, assuming a steady state, the export production must equal the new production fueled by new nutrients brought to the surface layers. The ef-ratio as a function of satellite-derived temperature and production can be obtained from the empirical relationship obtained by Laws et al. (2011):

$$
\begin{aligned}
e f & =\frac{(0.5857-0.0165 T) \mathrm{PP}}{(51.7+\mathrm{PP})}, \\
\mathrm{PP}_{\text {exp }} & =\mathrm{PP}_{\text {new }}=\mathrm{PP} \times e f, \\
\mathrm{PP}_{\text {reg }} & =\mathrm{PP}-\mathrm{PP}_{\text {new }},
\end{aligned}
$$

where $T$ is temperature in degrees Celsius $\left({ }^{\circ} \mathrm{C}\right)$ and $\mathrm{PP}$ is the daily production $\left(\mathrm{mg} \mathrm{C} \mathrm{m}^{-2}\right)$.

As shown in Table 1, we report PP as vertically integrated values ( $\mathrm{PP}$, in $\mathrm{g} \mathrm{C}^{-2}$ ), spatially integrated estimates for certain basins or regions ( $\Sigma \mathrm{PP}$, in Gt C), or mean volumetric values $\left(\mathrm{PPVOL}_{\mathrm{VOL}}\right.$, in $\left.\mathrm{g} \mathrm{C}^{-3}\right)$. The coefficient of variation $(\mathrm{CV})$ has been estimated for PP as the ratio of the standard deviation to the mean. While some authors include the Adriatic in the eastern basin (e.g., Bosc et al., 2004), we treated this region separately because its peculiarities (i.e., bathymetry, influence of rivers, eutrophic character) differentiate it from the rest of the Mediterranean Sea (Cushman-Roisin et al., 2001). Most of the Adriatic Sea has a shallow $(<200 \mathrm{~m})$ bathymetry, and it collects some $30 \%$ of the freshwater flowing into the Mediterranean, acting as a dilution basin for the nutrients discharged by the Po and other Adriatic rivers and becoming one of the most human-impacted regions of the Mediterranean Sea (Ludwig et al., 2009; Micheli et al., 2013; Raicich et al., 2013a).

\subsection{Coastal regionalization}

We used a two-step classification procedure to define coastal regions along the Mediterranean based on their temporal PP patterns. First, nine regions (R1 to R9) were identified using a classification technique based on an unsupervised learning neural network (self-organizing maps or SOMs; Kohonen, 1982, 2001). Then, 18 alongshore marine ecoregions were 
Table 1. Primary production acronyms used in this study, their units, and their definitions.

\begin{tabular}{|c|c|c|}
\hline Variable & Units & Definition \\
\hline $\mathrm{P}$ & $\mathrm{gCm}^{-3} \mathrm{~s}^{-1}$ & Instantaneous production at each depth $(z)$ of the water column \\
\hline PP & $\mathrm{gC} \mathrm{m}^{-2}$ & Daily primary production per surface unit; integration of $\mathrm{P}$ over depth and day length \\
\hline $\mathrm{PP}_{\text {annual }}$ & $\mathrm{gCm}^{-2}$ & Annual mean production per surface unit \\
\hline$\Sigma \mathrm{PP}$ & Gt C & Total carbon fixation per year within a basin or specific region \\
\hline $\mathrm{PP}_{\mathrm{VOL}}$ & $\mathrm{gCm}^{-3}$ & $\begin{array}{l}\text { Mean volumetric primary production; column-integrated PP divided by whichever is shallower } \\
\text { of the bottom depth or the productive layer }\end{array}$ \\
\hline $\mathrm{PP}_{\text {new }}$ & $\mathrm{gCm}^{-2}$ & New production (i.e., from allochthonous sources) \\
\hline $\mathrm{PP}_{\text {reg }}$ & $\mathrm{gC} \mathrm{m}^{-2}$ & Regenerated production \\
\hline
\end{tabular}

obtained considering the most relevant cross-shore limits of the SOM-derived regions ( $\mathrm{Z} 1$ to $\mathrm{Z} 18$ ).

SOM is an unsupervised neural network method that reduces the high-dimensional feature space of the input data to a lower-dimensional network of units called neurons. SOM is especially suited to extract patterns in large datasets of satellite data (Ben Mustapha et al., 2014; Charantonis et al., 2015; Farikou et al., 2015). Unlike other classification methods, like $k$-means, SOM tends to preserve data topology (i.e., preserves neighboring regions), and, therefore, it is particularly suited for pattern recognition (Liu and Weisberg, 2005). It allows adequate classification of areas with high spatial complexity and strong gradients. Similar neurons are mapped close together on the network, facilitating the visualization of patterns and a topological ordination of the classified areas, and the relative distance among neurons is obtained as a result of the analysis.

For typical satellite imagery, SOM can be applied to both space and time domains. Here, we have addressed the analysis in the time domain of the datasets, which allows regionalization of the studied area on the basis of similitudes in the time variation in PP. We chose a map size of $(3 \times 3)$, with nine neurons (for further details, see Basterretxea et al., 2018). We used a hexagonal map lattice in order to have equidistant neighbors and to avoid introducing anisotropy artifacts. For the algorithm initialization, we opted for linear mode, batch training algorithm, and ep, or Epanechnikov function, type neighborhood function since this parameter configuration produces the lower quantitative and topological error and computational cost (Liu et al., 2006). This methodology was applied in Basterretxea et al. (2018) for satellite-derived chlorophyll time series. For further details of the methodology used, see Hernández-Carrasco and Orfila (2018). These SOM computations were performed using the MATLAB toolbox of SOM v.2.0 (Vesanto et al., 2000a, b) provided by the Helsinki University of Technology (http://www.cis.hut.fi/somtoolbox/, last access: 12 April 2019).

\subsection{Climate data}

To identify possible drivers of long-term PP variability, we searched for correlations with two climate indices, the North Atlantic Oscillation (NAO) index and the Mediterranean Oscillation Index (MOI). The corresponding data were downloaded from the Climate Research Unit at the University of East Anglia (https://crudata.uea.ac.uk/cru/data/, last access: 21 August 2018) in monthly resolution. Climate indices are defined either as anomalies of a climate variable, using the difference between two geographical points, or as principal components (Hurrell, 1995).

NAO is the central mode of climate variability of the Northern Hemisphere atmosphere. It is based on the pressure difference between the middle of the North Atlantic Ocean and Iceland, which affects winter conditions in the North Hemisphere (Hurrell and Van Loon, 1997; Marshall et al., 2001). Positive NAO results in a relatively dry winter in the Mediterranean but a warmer and wetter winter in northern Europe, and vice versa. Because of its influence on precipitation, Mediterranean river inflows are generally anticorrelated with the NAO (Trigo et al., 2006).

MOI is the most widely used teleconnection index for the Mediterranean basin. It reflects differences in temperature, precipitation, circulation, evaporation, and other parameters between the eastern and western basin. There are different versions depending on the points of reference (CriadoAldeanueva and Soto-Navarro, 2013). We used the version obtained as the normalized pressure difference between Gibraltar and Israel (Palutikof, 2003). Positive MOI phases are associated with increased atmospheric pressure over the Mediterranean Sea that promotes a shift of the wind trajectories toward lower latitudes leading to milder winters (CriadoAldeanueva and Soto-Navarro, 2013). Under these conditions, reduced precipitation is observed in the southeastern Mediterranean region (Törnros, 2013). With some regional differences, $\mathrm{NAO}$ and $\mathrm{MOI}$ express relatively similar climate patterns over the Mediterranean Sea. They are highly positively correlated in winter and weakly but still significantly correlated in summer (Efthymiadis et al., 2011; MartínezAsensio et al., 2014). 


\subsection{Statistical analyses}

Linear temporal trends in the PP series were calculated using Theil-Sen slope adjustment (Sen, 1968) of the residuals of the de-seasonalized series. Time series have been deseasonalized by removing the $8 \mathrm{~d}$ climatological mean for the original time series. Time series with $>12 \%$ of missing values were excluded from the analysis, and the analysis was calculated pixel by pixel. A Mann-Kendall statistics test is applied to each pixel, and only pixels with a trend statistically significant at the $95 \%$ level were considered (Salmi et al., 2002). The use of this non-parametrical test is suitable for non-normally distributed data and has been previously used in the trend examination of remote-sensing chl time series (Colella et al., 2016; Kahru et al., 2011; Salgado-Hernanz et al., 2019).

\section{Results}

\subsection{Coastal primary production}

Annual primary production in coastal waters of the Mediterranean Sea $\left(\Sigma P P_{\text {Coast }}\right)$ is estimated to be $0.041 \pm 0.004 \mathrm{Gt} \mathrm{C}$, which represents some $12 \%$ of total carbon fixation in the Mediterranean Sea (see Tables 2 and 3). Approximately, $80 \%$ of this $\Sigma \mathrm{PP}_{\text {Coast }}$ is sustained by recycling processes, and, the rest, $\mathrm{PP}_{\text {new }}$, is exported to the seafloor or to nearby areas. Although average surface chl concentration is 3-fold higher in coastal areas $\left(0.3 \mathrm{mg} \mathrm{m}^{-3}\right)$ than in open areas $\left(0.11 \mathrm{mg} \mathrm{m}^{-3}\right)$, the annual carbon fixation per surface area $\left(\mathrm{PP}_{\text {annual }}\right)$ over the shelf is, on average, $26 \%$ lower than in the open ocean (100 \pm 91 and $136 \pm 40 \mathrm{~g} \mathrm{C} \mathrm{m}^{-2}$, respectively; see Tables 2 and 3). The lower $\mathrm{PP}_{\text {annual }}$ values on the coast are due to depth integration quite often being stopped at shallow depths, i.e., $Z_{\mathrm{b}}<Z_{\mathrm{p}}$.

Figure 2 reveals the differences in $\mathrm{PP}_{\text {annual }}$ between the more productive shelf waters in the western basin and those in the eastern basin $\left(90 \pm 39\right.$ and $\left.73 \pm 86 \mathrm{~g} \mathrm{Cm}^{-2}, p<0.001\right)$. The Adriatic shelf is by far the most productive, particularly if mean values are considered $\left(124 \pm 76 \mathrm{~g} \mathrm{Cm}^{-2}\right.$, Table 2). Annual carbon fixation is $97 \%$ higher in the eastern $\left(\Sigma P_{\text {east }}=0.021 \pm 0.002 \mathrm{GtC}\right)$ than in the western shelf $\left(\Sigma \mathrm{PP}_{\text {west }}=0.011 \pm 0.001 \mathrm{GtC}\right)$, which is due to greater eastern surface area (about twice the western surface area; Table 2). $\mathrm{PP}_{\text {annual }}$ varies spatially from 90 to $250 \mathrm{~g} \mathrm{Cm}^{-2}$ in the western shelf and from 50 to $400 \mathrm{~g} \mathrm{Cm}^{-2}$ in the eastern basin. Contrastingly, $\mathrm{PP}_{\text {annual }}$ exceeds $100 \mathrm{~g} \mathrm{C} \mathrm{m}^{-2}$ in the Adriatic basin, reaching values above $400 \mathrm{~g} \mathrm{Cm}^{-2}$ on the northwestern Adriatic coast (Fig. 2b). The most productive coastal regions $\left(>150 \mathrm{~g} \mathrm{Cm}^{-2}\right)$ are located in regions enriched by major river outflows. Indeed, the highest values of the coefficient of variation in primary production $\left(\mathrm{CV}_{\mathrm{PP}}\right)$ are observed at the mouth of the Nile, Ebro, Rhône, Tiber, Po, Neretva, or Nestos-Evros rivers. Nevertheless, in some
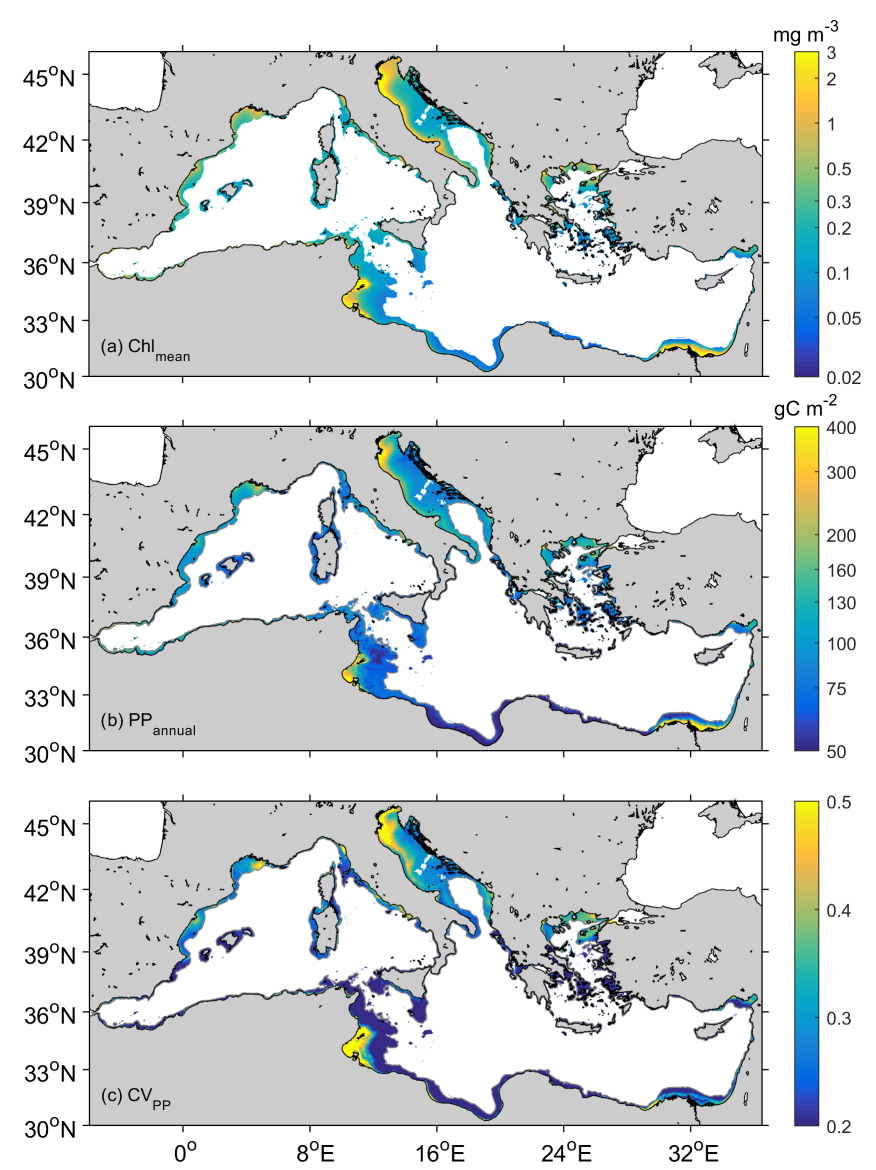

Figure 2. Mean distribution of (a) chlorophyll ( $\mathrm{chl}_{\text {mean }}$, in $\left.\mathrm{mg} \mathrm{m}^{-3}\right)$, (b) annual $\mathrm{PP}\left(\mathrm{PP}_{\text {annual }}\right.$, in $\left.\mathrm{g} \mathrm{C}^{-2}\right)$, and (c) coefficient of variation in $\mathrm{PP}$ values $\left(\mathrm{CV}_{\mathrm{PP}}\right)$.

coastal regions of the eastern basin like the Gulf of Gabès primary production is also outstandingly high $\left(>300 \mathrm{~g} \mathrm{Cm}^{-2}\right)$. Along the western North African coast, $\mathrm{PP}_{\text {annual }}$ also displays values $>150 \mathrm{~g} \mathrm{C} \mathrm{m}^{-2}$; however, since the shelf is narrow, its contribution to $\Sigma \mathrm{PP}_{\text {Coast }}$ is marginal (Figs. 1 and 2). The annual volumetric productivity follows a similar pattern than the annual integrated production, with most values varying between $1-3 \mathrm{~g} \mathrm{C} \mathrm{m}^{-3}$ but reaching up to $>10 \mathrm{~g} \mathrm{C} \mathrm{m}^{-3}$ in the most productive coastal regions of the Adriatic Sea and the Gulf of Gabès (Fig. 3a).

\subsection{Long-term variability and trends}

As shown in Fig. 4, variability in annual PP is dominated by short-scale variations (i.e., sub-decadal). The interannual variability is indicated by the low-frequency signal of the monthly mean anomalies. The filtered low-frequency signal to the anomalies of $\Sigma \mathrm{PP}$ and chl has been calculated using the MATLAB smooth function and applying the sgolay filter, which uses the Savitzky-Golay method, with a polynomial span degree of 17 . This degree was therefore filtering about 8 months before and after every time 
Table 2. Surface area and the corresponding basin percentage to surface area, (chl) \pm standard deviation (SD), $\Sigma P P$, the corresponding basin percentage to $\Sigma \mathrm{PP}_{\text {Coast }}\left(\% \Sigma \mathrm{PP}_{\text {Coast }}\right), \mathrm{PP}_{\text {annual }}$ median $\pm \mathrm{SD}\left(\mathrm{PP}_{\text {annual }}\right.$ mean), and $\mathrm{PP}$ VOL median $\pm \mathrm{SD}\left(\mathrm{PP} \mathrm{VOL}_{\mathrm{V}}\right.$ mean) for the Mediterranean Sea, open ocean waters, and coastal waters during the period 2002-2016. For $\Sigma \mathrm{PP}$ and $\mathrm{PP}_{\text {annual }}$, Mediterranean Sea values were obtained summing open ocean water values and coastal water values.

\begin{tabular}{|c|c|c|c|c|c|c|c|}
\hline & \multicolumn{2}{|c|}{ Surface area } & \multirow{2}{*}{$\begin{array}{r}\text { Chl } \\
\left(\mathrm{mg} \mathrm{m}^{-3}\right)\end{array}$} & \multirow{2}{*}{$\begin{array}{r}\Sigma \mathrm{PP} \\
(\mathrm{GtC})\end{array}$} & \multirow{2}{*}{$\begin{array}{r}\% \text { of } \\
\Sigma \mathrm{PP}_{\text {Coast }}\end{array}$} & \multirow{2}{*}{$\begin{array}{c}\mathrm{PP}_{\text {annual }} \\
\left(\mathrm{gC} \mathrm{m}^{-2}\right)\end{array}$} & \multirow{2}{*}{$\begin{array}{r}P_{\mathrm{VOL}} \\
\left(\mathrm{gC} \mathrm{m}^{-3}\right)\end{array}$} \\
\hline & $\left(10^{3} \mathrm{~km}^{2}\right)$ & $(\%)$ & & & & & \\
\hline Mediterranean Sea & 2504 & & $0.19 \pm 0.78^{\mathrm{a}}$ & $0.349 \pm 0.118^{\mathrm{c}}$ & & $140 \pm 40^{\mathrm{b}}$ & \\
\hline Open ocean waters & 1975 & & $0.11 \pm 0.18^{\mathrm{a}}$ & $0.308 \pm 0.118$ & & $136 \pm 40^{\mathrm{b}}$ & \\
\hline Coastal waters & 529 & 100 & $0.30 \pm 0.17$ & $0.041 \pm 0.004$ & 100 & $83 \pm 75(100)$ & $1.16 \pm 9.60(2.93)$ \\
\hline Western coast & 141 & 27 & $0.21 \pm 0.14$ & $0.011 \pm 0.001$ & 25 & $90 \pm 39(98)$ & $1.23 \pm 2.61(1.59)$ \\
\hline Eastern coast & 287 & 54 & $0.30 \pm 0.16$ & $0.021 \pm 0.002$ & 51 & $73 \pm 86(93)$ & $1.01 \pm 11.8$ \\
\hline Adriatic coast & 101 & 19 & $0.39 \pm 0.23$ & $0.010 \pm 0.001$ & 24 & $99 \pm 76(124)$ & $1.50 \pm 7.23(3.27)$ \\
\hline
\end{tabular}

${ }^{a}$ Mean surface chl values obtained by averaging the $8 \mathrm{~d}$ and $4 \mathrm{~km}$ resolution of surface satellite chl values obtained from CMEMS (Salgado-Hernanz et al., 2019). ${ }^{\mathrm{b}}$ PP estimated by averaging published satellite data shown in Table $3 .^{\mathrm{c}} \Sigma \mathrm{PP}$ estimated adding coastal water data from this study to open ocean water data obtained from Table 3.
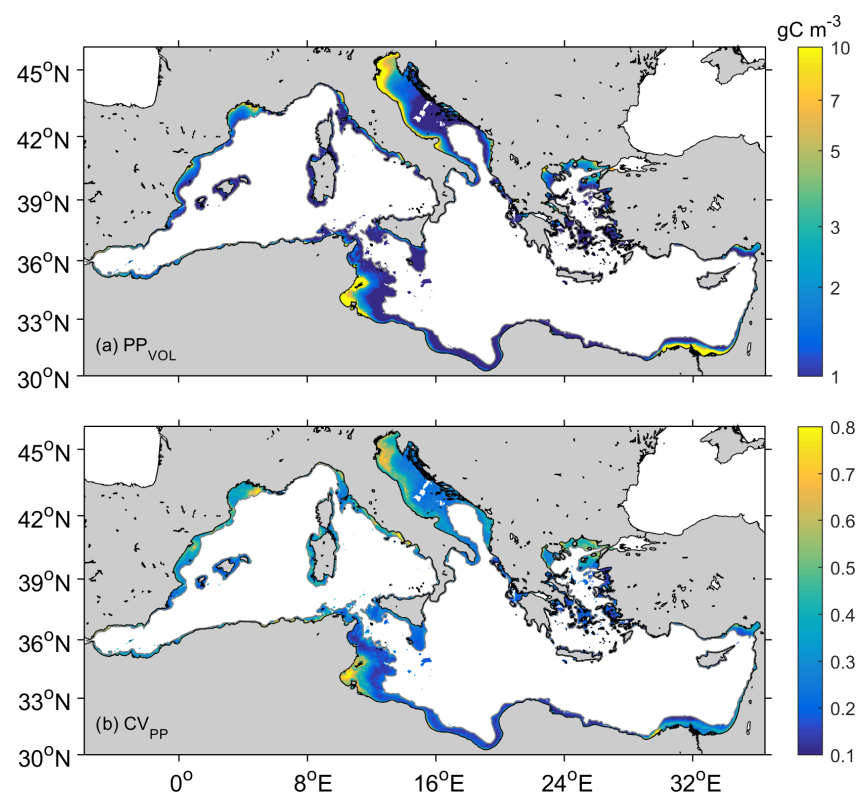

Figure 3. Mean distribution of (a) volumetric $\mathrm{PP}\left(\mathrm{PP}_{\mathrm{VOL}}\right.$, in $\mathrm{g} \mathrm{C} \mathrm{m}^{-3}$ ) and (b) coefficient of variation in volumetric PP values $\left(\mathrm{CV}_{\mathrm{PP}}\right)$.

step (about 1.5 years), then showing interannual variability. $\Sigma \mathrm{PP}_{\text {Coastal }}$ exhibits moderate interannual variability (up to $25 \%$ ) whereas basin-scale interannual variations range from $26 \%$ in the Adriatic basin up to $28 \%$ in the western basin and $29 \%$ in the eastern basin. This value of interannual variability was calculated subtracting the year with the minimum annual PP from the year with the maximum annual PP and then dividing this value by the mean annual PP. Positive anomalies in $\Sigma P P_{\text {Coastal }}$ extended between 2004 and 2011 (mean $\Sigma \mathrm{PP}_{\text {Coastal }}=0.044 \pm 0.001 \mathrm{GtC} \mathrm{yr}^{-1}$ for the whole basin between those years, Fig. 4a and Appendix Fig. A1a). Conversely, the year 2012 was particularly unproductive in all three basins $(0.037$ for the whole basin, 0.010 for the western basin, 0.019 for the eastern basin, and $0.009 \mathrm{GtC} \mathrm{yr}^{-1}$ for the Adriatic basin). This negative anomaly marked the beginning of a less productive period, particularly noticeable in the eastern basin (Figs. 4, A1 and A2). $\mathrm{PP}_{\text {annual }}\left(\mathrm{g} \mathrm{Cm}^{-2}\right)$ and $\Sigma \mathrm{PP}(\mathrm{GtC})$ in every year are shown in Figs. A1 and A2.

As revealed by Fig. 5a, some regionally coherent patches of significant trend in PP are observed along the coast. Most of these regions presented declining PP trends, particularly along the North African coast where SST is increasing at a higher rate (Fig. 5b). Typical PP trend magnitudes observed along the Spanish Mediterranean and the North African coast from the Gulf of Gabès range from -0.05 to $+0.05 \mathrm{~g} \mathrm{C} \mathrm{m}^{-2}$ per decade. Some positive PP trends, exceeding $+0.1 \mathrm{~g} \mathrm{Cm}^{-2}$ per decade, can be determined in some coastal regions north of the Adriatic Sea.

A significant negative correlation was observed between monthly coastal anomalies of $\Sigma$ PP and SST at the whole Mediterranean basin scale $(r=-0.66, p<0.001$; Fig. 6a, Table A1), revealing a decrease in phytoplankton biomass as the sea warms up. In addition, we observed evidence of an inverse relationship between PP variability and the phase of the climate indices NAO and MOI $(r=-0.46, p<0.001$, and $r=-0.24, p<0.001$, respectively; Fig. $6 \mathrm{~b}$ and c, Table A1). A similar relationship is observed between monthly coastal chl anomalies with SST $(r=-0.64, p<0.001)$ and climate indices NAO and MOI $(r=-0.60, p<0.001$, and $r=-0.35, p<0.001$, respectively; see Appendix Fig. A3) at the whole Mediterranean basin scale.

Additionally, the response of PP to climate variations varied seasonally. Indeed, NAO influenced coastal PP in summer, both in the western and in the eastern basin $(r=0.25$, $p=0.06 ; r=0.22, p=0.08$, respectively) and MOI variations were better correlated with PP global variations in spring $(r=0.28, p=0.04)$, showing a higher impact in the Adriatic basin $(r=0.37, p=0.02)$. No significant correlation was found during the winter or fall season for any index 
Table 3. Compilation of published values of $\mathrm{PP}_{\text {annual }}$ and $\Sigma \mathrm{PP}$ for the different Mediterranean basins.

\begin{tabular}{|c|c|c|c|c|c|}
\hline \multirow[t]{2}{*}{ Region } & \multirow{2}{*}{$\begin{array}{l}\text { Period } \\
\text { (years) }\end{array}$} & \multirow{2}{*}{$\begin{array}{l}\mathrm{PP}_{\text {annual }} \\
\left(\mathrm{gC} \mathrm{m}^{-2}\right)\end{array}$} & \multirow{2}{*}{$\begin{array}{l}\Sigma \mathrm{PP} \\
(\mathrm{GtC})\end{array}$} & \multirow[t]{2}{*}{ Method } & \multirow[t]{2}{*}{ Reference } \\
\hline & & & & & \\
\hline \multirow{8}{*}{$\begin{array}{l}\text { Whole } \\
\text { Mediterranean } \\
\text { estimation }\end{array}$} & - & \multicolumn{2}{|l|}{$80-90$} & In situ ( ${ }^{14} \mathrm{C}$ method) & Sournia (1973) \\
\hline & 1981 & \multicolumn{2}{|c|}{$94 \pm 60-117.5 \pm 75^{\mathrm{a}}$} & Satellite (CZCS) & Morel and André (1991) \\
\hline & 1979-1983 & $125-156^{\mathrm{a}}$ & $0.308-0.385^{\mathrm{a}}$ & Satellite (CZCS) & Antoine and André (1995) \\
\hline & 1997-1998 & 190 & & Satellite (SeaWiFS) & Bricaud et al. (2002) \\
\hline & 1998-2001 & $79.1-88.4$ & & Satellite (SeaWiFS) & Colella et al. (2003) \\
\hline & 1998-2001 & $130-140$ & & Satellite (SeaWiFS) & Bosc et al. (2004) \\
\hline & 1998-2007 & & 0.5 & Satellite (SeaWiFS) & Uitz et al. (2010) \\
\hline & 1998-2013 & 116 & & Satellite (five sensors) & O'Reilly and Sherman (2016) \\
\hline \multirow{12}{*}{$\begin{array}{l}\text { Western } \\
\text { basin }\end{array}$} & 1980-1985 & 120 & & In situ (Oxygen) & Bethoux (1989) \\
\hline & 1981 & 157.7 & & Satellite (CZCS) & Morel and André (1991) \\
\hline & 1979-1983 & $157-197^{\mathrm{a}}$ & & Satellite (CZCS) & Antoine and André (1995) \\
\hline & 1996 & $140-150$ & & In situ $\left({ }^{14} \mathrm{C}\right.$ data $)$ & Conan et al. (1998) \\
\hline & 1997-1998 & 198 & & Satellite (SeaWiFS) & Bricaud et al. (2002) \\
\hline & 1991-1999 & $83-235$ & & In situ ( ${ }^{14} \mathrm{C}$ method $)$ & Marty et al. (2002) \\
\hline & 1996 & 175 & & In situ $\left({ }^{14} \mathrm{C}\right.$ method $)$ & Moutin and Raimbault (2002) \\
\hline & 1997-1998 & 123 & & In situ ( ${ }^{14} \mathrm{C}$ method) & Van Wambeke et al. (2004) \\
\hline & 1997-1998 & 152 & & In situ ( ${ }^{14} \mathrm{C}$ method) & Lefèvre unpubl. (2001)* \\
\hline & 1998-2001 & $93.8-98.8$ & & Satellite (SeaWiFS) & Colella et al. (2003) \\
\hline & 1998-2001 & $163 \pm 7$ & & Satellite (SeaWiFS) & Bosc et al. (2004) \\
\hline & 2006-2007 & $858^{\mathrm{c}, \mathrm{d}}$ & & In situ (dark-light method) & Regaudie-De-Gioux et al. (2009) \\
\hline \multirow{8}{*}{$\begin{array}{l}\text { Eastern } \\
\text { basin } \\
\text { (including } \\
\text { Adriatic) }\end{array}$} & 1980-1985 & $137-150^{\mathrm{b}}$ & & In situ (Phosphorous) & Béthoux et al. (1998) \\
\hline & 1981 & 109.4 & & Satellite (CZCS) & Morel and André (1991) \\
\hline & 1979-1983 & $110-137^{\mathrm{a}}$ & & Satellite (CZCS) & Antoine and André (1995) \\
\hline & 1997-1998 & 183 & & Satellite (SeaWiFS) & Bricaud et al. (2002) \\
\hline & 1996 & 96 & & In situ $\left({ }^{14} \mathrm{C}\right.$ data $)$ & Moutin and Raimbault (2002) \\
\hline & 1998-2001 & $69.1-81.5$ & & Satellite (SeaWiFS) & Colella et al. (2003) \\
\hline & 1998-2001 & $121 \pm 5$ & & Satellite (SeaWiFS) & Bosc et al. (2004) \\
\hline & 2006-2007 & $521^{\mathrm{c}, \mathrm{d}}$ & & In situ (dark-light method) & Regaudie-De-Gioux et al. (2009) \\
\hline \multirow{2}{*}{$\begin{array}{l}\text { Adriatic } \\
\text { basin }\end{array}$} & $1978-1983$ & $241-301^{\mathrm{a}}$ & 0.0235 & Satellite (CZCS) & Antoine and André (1995) \\
\hline & 1998-2001 & $92.4-104.4$ & & Satellite (SeaWiFS) & Colella et al., (2003) \\
\hline
\end{tabular}

${ }^{\mathrm{a}}$ The estimates from Antoine et al. (1995) and Morel and André (1991) have been corrected by a factor of 1.25 as recommended by Morel et al. (1996). ${ }^{\mathrm{b}}$ From Colella et al. (2003), who estimated it using $f$-ratios (the ratio between new and total PP) obtained from Boldrin et al. (2002). ${ }^{\mathrm{c}} \mathrm{Daily}$ PP (mg Cm ${ }^{-2} \mathrm{~d}^{-1}$ ) converted to annual $\mathrm{PP}\left(\mathrm{mg} \mathrm{Cm}^{-2} \mathrm{yr}^{-1}\right)$ multiplied by $365 .{ }^{\mathrm{d}}$ Conversion to carbon unit using photosynthetic quotient $P Q=1{ }^{*}$ Data included in the Data Published for Earth and Environmental Science PANGAEA data collection.

(see Table A1 in Appendix). Correlation analyses were performed using the Pearson product moment correlation. Differences between means were tested using the KolmogorovSmirnov test (Massey et al., 1951).

\subsection{Coastal regionalization}

The nine characteristic temporal PP patterns, their corresponding spatial distribution obtained from the SOM analysis, and the 18 zones in which the coastal region was classified are shown in Fig. 7. Generally, wider shelves present higher spatial complexity manifested as a larger number of SOM patterns. About $78 \%$ of the shelf waters include $\mathrm{R} 1, \mathrm{R} 2, \mathrm{R} 3$, and R4 patterns. In particular, R1 and R2 characterize areas of low production, with scarce season- ality $\left(\mathrm{PP}_{\text {annual }}=44 \pm 17\right.$ and $69 \pm 22 \mathrm{~g} \mathrm{Cm}^{-2}$, respectively; Table 4) typically occurring in the southern and eastern Mediterranean (12\% and $29 \%$ of the total surface area). They are representative of the productivity patterns in vast shelf regions in the Gulf of Gabès and Sirte and in the central Aegean (Z17, Z16, Z14 and Z11). R3 and R4 correspond to higher production and a wider range of variation $\left(\mathrm{PP}_{\text {annual }}=90 \pm 32\right.$ and $98 \pm 39 \mathrm{~g} \mathrm{C}^{-2}$; Table 4 and Fig. 7$)$. While R3 (18.6\% of total coastal surface) is frequent in shelf regions of the western basin (Z2, Z3, Z5, and Z7), R4 extends over the deepest areas of the Adriatic Sea (Z9 and Z10). Both patterns are representative of variations observed in $36.9 \%$ of the coastal waters.

As shown in Table 4, areas of low production with seasonal patterns R1 to R4 contribute to more than $62 \%$ of 

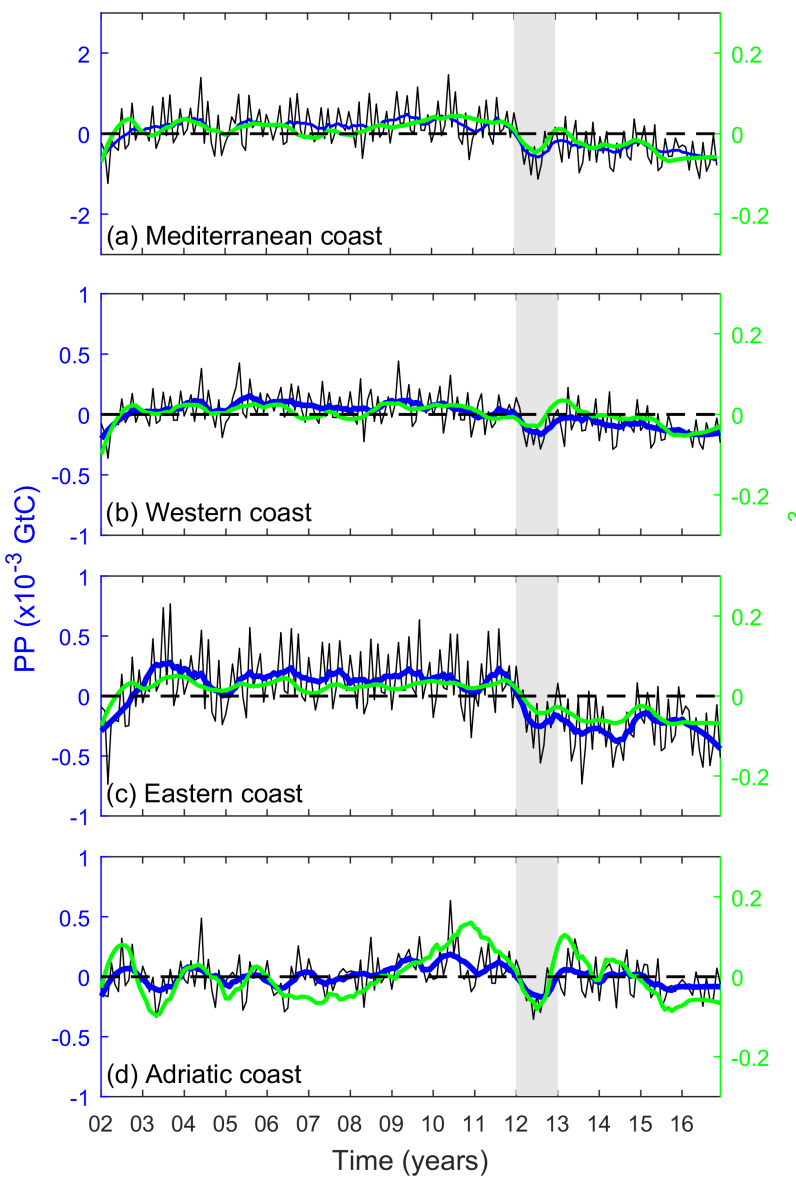

Figure 4. PP variability and trends for coastal waters in (a) the whole Mediterranean Sea, (b) western basin, (c) eastern basin, and (d) Adriatic coast. Black solid lines indicate the original monthly $\Sigma P_{\text {Coastal }}$ anomalies, and the filtered low-frequency signal is overlaid in blue (16-month width sgolay filter). Green solid lines indicate the filtered low-frequency signal for chl anomalies $\left(\mathrm{mg} \mathrm{m}^{-3}\right)$. The red line indicates the PP trend during the analyzed period (2002-2016), and the gray band indicates the year 2012.

total pelagic carbon fixation in Mediterranean coastal areas. In contrast, systems of higher production $\left(\mathrm{PP}_{\text {annual }}>\right.$ $280 \mathrm{~g} \mathrm{C} \mathrm{m}^{-2} \mathrm{~d}^{-1}$ ) barely contribute to $17 \%$ of total production. These regions of enhanced production are generally constrained to regions of freshwater influence (ROFIs; Simpson, 1997) where terrestrial nutrients fuel coastal production. Indeed, R8 is almost exclusively restricted to the river mouths, and it presents elevated $\mathrm{PP}_{\text {annual }}$ values $(1.29 \pm$ $0.50 \mathrm{~g} \mathrm{C} \mathrm{m}^{-2} \mathrm{~d}^{-1}$ ) and a wide range of variation of 0.67 to $2.14 \mathrm{~g} \mathrm{C} \mathrm{m}^{-2} \mathrm{~d}^{-1}$. An exception is the $\mathrm{R} 7$ pattern, which is exclusively located in the shallowest inner shelf of the Gulf of Gabès, and it is bounded by R5, a transition region between the inner and outer shelf. Unlike the other regions, where PP peaks in late winter-spring, maximum PP in R7 occurs in fall. Finally, R5 and R6 patterns correspond to transition regions accounting for $20.4 \%$ of the total pro-

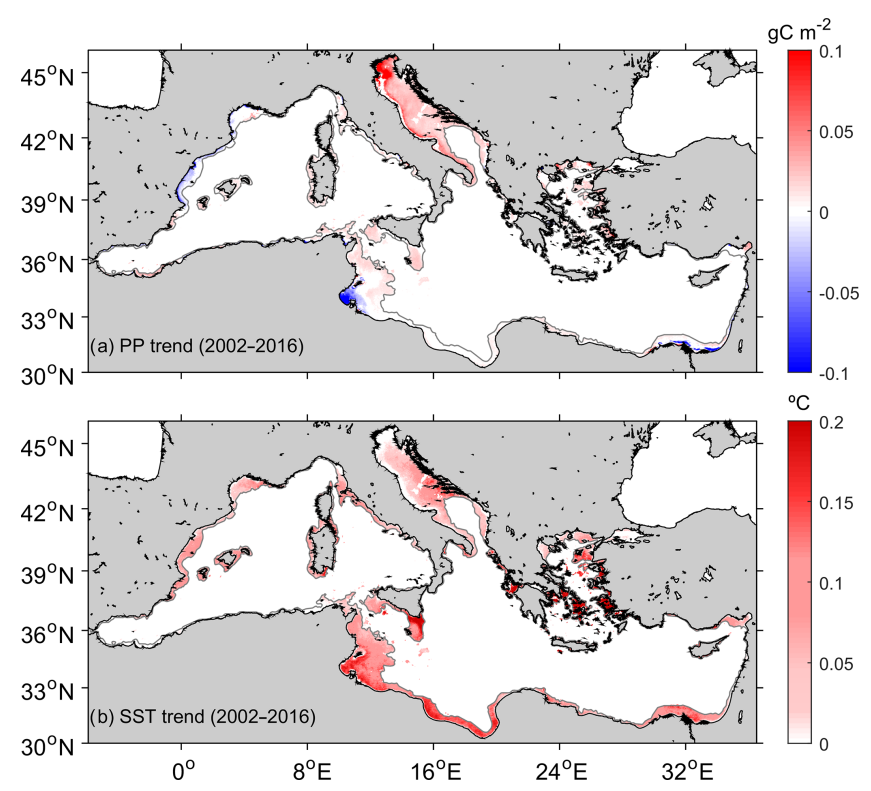

Figure 5. Trends in primary production and sea surface temperature. Values correspond to the change per decade. (a) Theil-Sen trend in pelagic primary production (PP trend) estimated from daily values for the 2002-2016 period. (b) Trend in sea surface temperature (SST trend). Only significant trends $(p<0.05)$ are shown.
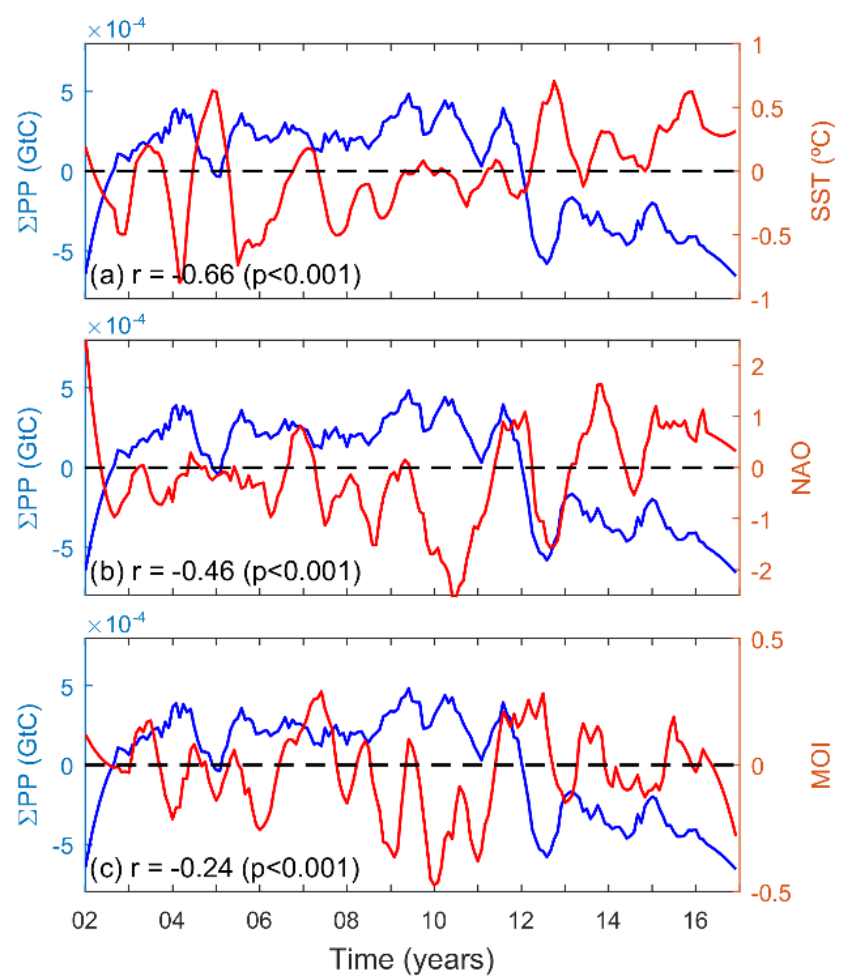

Figure 6. Relationship between coastal pelagic primary production ( $\Sigma$ PP anomalies, blue lines) and (a) SST anomalies, (b) NAO index, and (c) MOI index (red lines). 
(a)
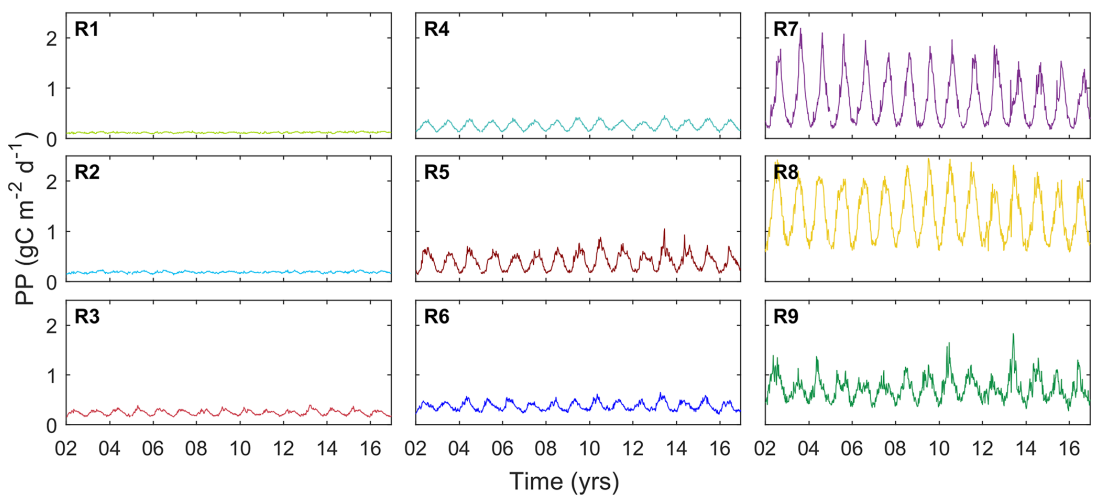

(b)

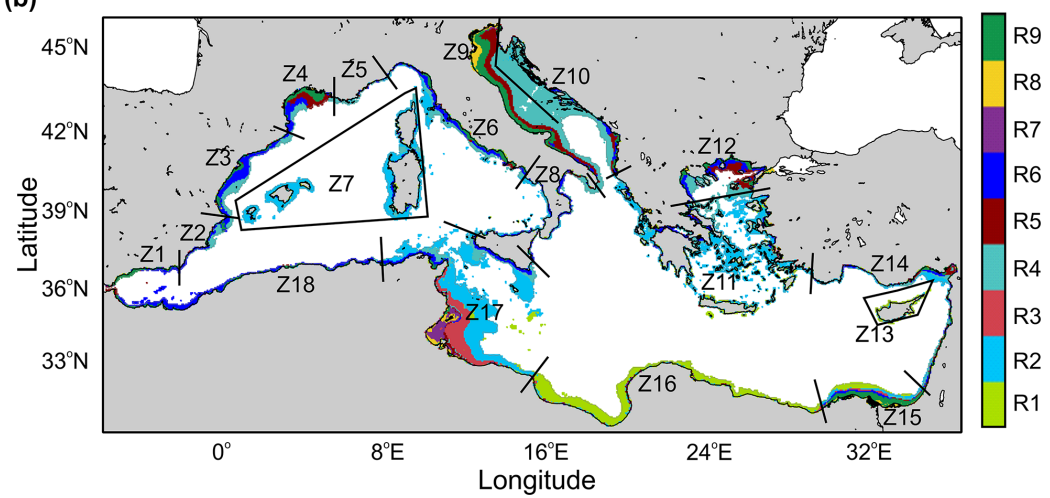

Figure 7. Regionalization of the coastal waters in the Mediterranean Sea based on their temporal patterns of pelagic primary production. (a) Characteristic temporal patterns of PP obtained from SOM classification (R1 to R9) and (b) coastal regions defined from alongshore variations in the $\mathrm{SOM}$ - regions ( $\mathrm{Z1}$ to $\mathrm{Z} 18$ ).

Table 4. Extension and primary production for each of the SOMdefined regions (R1 and R9). Mean annual PP is estimated by averaging mean daily $\mathrm{PP}$ and then multiplying it by the number of days of the year, i.e., 365 .

\begin{tabular}{lrrrrr}
\hline & \multicolumn{2}{c}{ Area } & \multirow{2}{*}{$\mathrm{PP}_{\text {annual }}$} & \multicolumn{2}{c}{$\Sigma \mathrm{PP}$} \\
\cline { 6 - 6 } & $\left(\mathrm{km}^{2}\right)$ & $(\%)$ & $\left(\mathrm{g} \mathrm{Cm}^{-2}\right)$ & $\left(10^{-3} \mathrm{GtC}\right)$ & $(\%)$ \\
\hline $\mathrm{R} 1$ & 61052 & 12.2 & $44 \pm 17$ & $1.98 \pm 0.24$ & 4.8 \\
$\mathrm{R} 2$ & 149766 & 29.0 & $69 \pm 22$ & $8.89 \pm 0.66$ & 21.5 \\
$\mathrm{R} 3$ & 94562 & 18.6 & $90 \pm 32$ & $7.31 \pm 0.54$ & 17.6 \\
$\mathrm{R} 4$ & 93103 & 18.3 & $98 \pm 39$ & $7.81 \pm 0.45$ & 18.8 \\
$\mathrm{R} 5$ & 22566 & 5.0 & $154 \pm 102$ & $2.95 \pm 0.27$ & 7.1 \\
$\mathrm{R} 6$ & 47977 & 9.8 & $140 \pm 70$ & $5.50 \pm 0.58$ & 13.3 \\
$\mathrm{R} 7$ & 5816 & 1.8 & $288 \pm 217$ & $1.41 \pm 0.24$ & 3.4 \\
$\mathrm{R} 8$ & 7822 & 2.2 & $508 \pm 283$ & $2.67 \pm 0.67$ & 6.5 \\
$\mathrm{R} 9$ & 13181 & 3.2 & $281 \pm 175$ & $2.95 \pm 0.38$ & 7.1 \\
\hline
\end{tabular}

duction and $14.8 \%$ of the Mediterranean coast. While R5 mainly occurs in deltas, R6 is characteristic of the western Mediterranean shelf, including the North African coast (0.36-0.08 $\mathrm{g} \mathrm{C} \mathrm{m}^{-2} \mathrm{~d}^{-1}$; Fig. 7).
The SOM-based regionalization reveals two groups of coastal waters: those with low cross-shore variability and including only one or two SOM regions (i.e., Z1, Z13, Z16, and Z18) and those with strong cross-shore gradients including several SOM regions (i.e., Z4, Z9, Z12, Z15). The first pattern is typically observed in narrow continental shelf areas with low influence of river inputs whereas the second group is found in regions with a wider continental shelf such as ROFIs (the Rhône delta, the north and western coastline of the Adriatic Sea, and the Nile Delta) and in the Gulf of Gabès. The western Adriatic (Z9) and the Gulf of Gabès (Z17) are the largest contributors to $\Sigma \mathrm{PP}_{\text {Coast }}$, together contributing $35.9 \%$ of shelf production in the Mediterranean Sea, but, in the case of Z17, it is mainly due to its large extension (Table 5). PP is also high in the northern Alboran Sea (Z1), Nile delta (Z15), the western Adriatic (Z9), and Gulf of Lion (Z4; Table 5). With the exception of Z1, influenced by the entrance of waters from the Atlantic Ocean and by local coastal upwelling, these zones receive important riverine fluxes $(Q)$. 


\section{Discussion}

\subsection{Coastal primary production}

In this study we focused on the contribution of coastal waters to the overall pelagic PP in the Mediterranean Sea. While the mean coastal values for the Mediterranean $\left(100 \pm 91 \mathrm{~g} \mathrm{C} \mathrm{m}^{-2}\right)$ are somewhat lower than the mean values over the continental shelves of the world ocean $\left(160 \pm 40 \mathrm{~g} \mathrm{Cm}^{-2}\right.$; Smith and Hollibaugh, 1993), the impact of coastal pelagic PP on total basin production (12\%) is in the high range of the estimations for other seas (Muller-Karger et al., 2005). This estimation is subject to the uncertainties inherent to using satellite ocean color, which is limited to the upper ocean (down to $20 \mathrm{~m}$ at best in clear waters) and has poor performance in some areas (i.e., Case-2 waters). It nevertheless provides an assessment of net rates of carbon fixation in coastal areas that is consistent with global estimations of the contribution of coastal areas to oceanic production (Gattuso et al., 1998; Ducklow and McCallister, 2004; MullerKarger et al., 2005). Bias in coastal chl estimations is mainly due to the presence of non-phytoplankton components such as colored dissolved organic matter (CDOM) or other terrestrial substances (Morel et al., 2006). These compounds originate from coastal erosion, resuspension in shallow areas, river inputs, or anthropogenic effluents. Likewise, they affect the propagation of photosynthetic radiation through the water column (Morel, 1991). However, the possible uncertainties and biases caused by chl estimation through satellite data might very weakly alter our estimation of coastal PP. Indeed, previous studies agreed that Case- 1 waters are largely predominant in the coastal Mediterranean regions whereas Case-2 waters are reduced to less than $5 \%$ of the whole basin (Antoine and André, 1995; Bosc et al., 2004; Bricaud et al., 2002). This constitutes some $23 \%$ of the coastal waters with prevalence in the north Adriatic Sea, Gulf of Gabès, and around the Nile delta. In particular, they are confined to the north Adriatic Sea, Gulf of Gabès, and around the Nile delta where our PP estimations may present larger uncertainties (Antoine and André, 1995). However, $\mathrm{PP}_{\text {annual }}$ values off the Nile River delta, $>100 \mathrm{~g} \mathrm{Cm}^{-2}$ estimated here, are only slightly higher than those reported by Antoine et al. (1995) (80-100 $\left.\mathrm{g} \mathrm{C} \mathrm{m}^{-2}\right)$. The highest values have been reported for this region (> $300 \mathrm{~g} \mathrm{Cm}^{-2}$ ), but, as shown in Fig. 2, they are restricted to a narrow coastal band. In the case of the Adriatic Sea, Umani (1996) reported values of PP from 50 to $200 \mathrm{~g} \mathrm{C} \mathrm{m}^{-2} \mathrm{yr}^{-1}$, while Zoppini et al. (1995) estimated PP rates from 210 to $260 \mathrm{~g} \mathrm{Cm}^{-2} \mathrm{yr}^{-1}$ in the northern coastal areas. Our estimations range between 100 and $>350 \mathrm{~g} \mathrm{Cm}^{-2}$ (with mean values of $123 \pm 106 \mathrm{~g} \mathrm{Cm}^{-2}$ ).

Contrary to what we would have expected, we observed that the eastern basin contributes more than the western basin to overall coastal production ( $51 \%$ and $25 \%$, respectively; Table 2). Its great extension (twice higher than the western basin) and the increased productivity in regions like Gabès, the Nile, and the northern Aegean Sea may explain greater coastal PP in the eastern basin than in the western basin. Additionally, due to the lack of large shallow and productive areas in the western basin, we observed few volumetric PP values above $30 \mathrm{~g} \mathrm{C} \mathrm{m}^{-3}$ in the western Mediterranean whereas high volumetric PP is more frequent in the Adriatic Sea and in the eastern Mediterranean, in shallow waters of the Gulf of Gabès, and in the Nile delta. Furthermore, carbon fixation from the Adriatic Sea represents $24 \%$ of total coastal production, which is significant considering the area of this sea (19\% of Mediterranean coastal waters). The relevance of the contribution of the Adriatic Sea in overall coastal PP lies in two main characteristics: $(1)$ coastal waters $(<200 \mathrm{~m})$ constitute a large part of the Adriatic Sea, and (2) about one-third of the river discharge in the Mediterranean is concentrated in the Adriatic Sea (see Table 5). Indeed, patterns in the northern Adriatic Sea reflect a variation in the drivers of PP with respect to other regions. For example, while internal processes (i.e., vertical diffusion and mixing) and atmospheric deposition drive PP in most coastal waters, production in the north Adriatic is mainly driven by fluvial sources of carbon and regeneration through bacterial pathways (Powley et al., 2016; Rodellas et al., 2015; Umani et al., 2007). Moreover, distinctive dynamics in this sea is driven by the influence of river outflows on stratification and general circulation patterns (Djakovac et al., 2012; Giani et al., 2012).

Regionally, the Alboran Sea, the Gulf of Lion, the Adriatic Sea, the Aegean Sea, the Nile delta, and particularly the Gulf of Gabès (up to $23 \%$ of total coastal production) are the most productive zones. While some of these productive (i.e., $\mathrm{PP}_{\mathrm{VOL}}>3 \mathrm{~g} \mathrm{C}^{-3}$ ) coastal regions are located in areas affected by river outflows, this type of production rapidly decreases in the offshore direction (see Fig. 3). Exceptions are the Rhône and the Po and less so the Nile, the influence of which extends far along the shelf. Other processes like mesoscale circulation are also important in some of these regions (i.e., Gulf of Lion), as demonstrated by Macias et al. (2017). Additionally, the exchanges with the more productive Atlantic and Black Sea waters in Alboran and in the northern Aegean and local enrichment processes in the Gulf of Gabès are major contributors to coastal productivity. Indeed, the Gulf of Gabès constitutes an anomaly in the eastern Mediterranean basin. Its shallowness $(<50 \mathrm{~m}$ depth at $110 \mathrm{~km}$ off the coast), unique tidal range (maximum $>2 \mathrm{~m}$ ) promoting vertical mixing, and the lack of summer nutrient exhaustion undoubtedly contribute to its high productivity (Béjaoui et al., 2019).

Notwithstanding the importance of land inputs in the production of coastal Mediterranean waters, from $e f$-ratios, we estimated that on average only $22 \% \pm 20 \%$ of the production is new, and the rest is sustained via regenerated sources (Fig. 8a-c). This $\mathrm{PP}_{\text {new }}$ value (Fig. 8 b) is comparable to the mean organic carbon that sinks to the sea floor (28\%) estimated from Muller-Karger et al. (2005) and Pace et al. (1987) but higher than $\mathrm{PP}_{\text {new }}$ estimations provided by Vidussi et al. 
Table 5. Surface, river discharge flow $(Q)$, annual mean $\mathrm{PP}\left(\mathrm{PP}_{\text {annual }}\right)$, annual integrated $\mathrm{PP}(\Sigma \mathrm{PP})$, and its contribution with respect to the total coastal Mediterranean Sea PP for each of the 18 alongshore zones characterized in the Mediterranean Sea. Mean and standard deviation (SD) are calculated from 15-year averages (2002-2016). River discharge flow was extracted from Tockner et al. (2008).

\begin{tabular}{lrrrrrr}
\hline & \multicolumn{2}{c}{ Area } & & $Q$ & $\mathrm{PP}_{\text {annual }}$ & \multicolumn{2}{c}{$\Sigma$ PP } \\
\cline { 2 - 3 } \cline { 5 - 7 } & $\left(\mathrm{km}^{2}\right)$ & $(\%)$ & $\left(\mathrm{km}^{3} \mathrm{yr}^{-1}\right)$ & $\left(\mathrm{g} \mathrm{Cm}^{-2}\right)$ & $\left(10^{-3} \mathrm{GtC}\right)$ & $(\%)$ \\
\hline $\mathrm{Z} 1$ & 1869 & 0.4 & 0.5 & $215 \pm 124$ & $0.22 \pm 0.05$ & 0.4 \\
$\mathrm{Z} 2$ & 7226 & 1.4 & 1.2 & $107 \pm 58$ & $0.62 \pm 0.08$ & 1.4 \\
$\mathrm{Z3}$ & 18870 & 3.6 & 21.4 & $104 \pm 47$ & $1.71 \pm 0.16$ & 3.6 \\
$\mathrm{Z} 4$ & 15196 & 2.9 & 57.7 & $128 \pm 72$ & $1.61 \pm 0.12$ & 2.9 \\
$\mathrm{Z} 5$ & 878 & 0.2 & 1.9 & $84 \pm 33$ & $0.04 \pm 0.02$ & 0.2 \\
$\mathrm{Z} 6$ & 20392 & 3.9 & 14.6 & $101 \pm 64$ & $1.62 \pm 0.20$ & 3.9 \\
$\mathrm{Z} 7$ & 29666 & 5.7 & 0.5 & $74 \pm 26$ & $1.66 \pm 0.20$ & 5.7 \\
$\mathrm{Z} 8$ & 8178 & 1.6 & 3.7 & $81 \pm 34$ & $0.40 \pm 0.09$ & 1.6 \\
$\mathrm{Z} 9$ & 64780 & 12.4 & 70.5 & $140 \pm 124$ & $7.63 \pm 0.66$ & 12.4 \\
$\mathrm{Z} 10$ & 40997 & 7.8 & 35.8 & $89 \pm 37$ & $2.81 \pm 0.25$ & 7.8 \\
$\mathrm{Z} 11$ & 58252 & 11.1 & 21.5 & $81 \pm 59$ & $2.95 \pm 0.67$ & 11.1 \\
$\mathrm{Z} 12$ & 25720 & 4.9 & 21.2 & $123 \pm 76$ & $2.25 \pm 0.33$ & 4.9 \\
$\mathrm{Z} 13$ & 30,71 & 0.6 & 0 & $53 \pm 18$ & $0.09 \pm 0.02$ & 0.6 \\
$\mathrm{Z} 14$ & 16814 & 3.2 & 21.3 & $97 \pm 61$ & $1.21 \pm 0.14$ & 3.2 \\
$\mathrm{Z} 15$ & 28544 & 5.5 & 17 & $170 \pm 182$ & $4.02 \pm 0.50$ & 5.5 \\
$\mathrm{Z} 16$ & 46065 & 8.8 & 0 & $48 \pm 17$ & $1.85 \pm 0.12$ & 8.8 \\
$\mathrm{Z} 17$ & 123071 & 23.5 & 1.1 & $90 \pm 87$ & $9.72 \pm 0.80$ & 23.5 \\
$\mathrm{Z} 18$ & 13411 & 2.6 & 6.1 & $125 \pm 56$ & $1.24 \pm 0.18$ & 2.6 \\
\hline
\end{tabular}

(2001) for oceanic waters in the eastern basin (15\% of total production). Contrarily to Vidussi et al. (2001), who estimated $\mathrm{PP}_{\text {new }}$ in the eastern basin, the coastal $\mathrm{PP}_{\text {new }}$ average here includes both eastern and western basins of the Mediterranean, but also the highly productive areas in the northern Adriatic. This could explain why the $\mathrm{PP}_{\text {new }}$ observed here is higher than the one observed for oceanic waters in the eastern basins. Additionally, high ef-ratios (>0.3) are observed in our case in the areas where nutrient inputs from the Atlantic and river effluents significantly enhance $\mathrm{PP}_{\text {new }}$ (Fig. 8a). Furthermore, ef-ratios present significant seasonality, varying between $0.26 \pm 0.04$ in the most productive winter-spring season and $0.15 \pm 0.02$ in summer, when the water column is strongly stratified and the food web shifts to a more recycling-dominated system.

\subsection{Long-term variability and trends}

Available satellite ocean color data span about 20 years, so that temporal trends derived from their analysis highly depend on decadal variability (Henson et al., 2010). Despite these limitations, satellite observations of ocean color over the past 2 decades suggest a relationship between warming and reduced productivity in permanently stratified areas (Behrenfeld et al., 2006). Since clear tendencies of warming are observed in the Mediterranean Sea (Nykjaer, 2009; Pastor et al., 2018), intensification of stratification would decrease nutrient supply to phytoplankton and, thus, decrease PP (Behrenfeld et al., 2006; Stambler, 2014).
Barale et al. (2008), using chl anomalies derived from SeaWiFS data, observed a general decrease in chl biomass in the Mediterranean Sea over the period 1998-2003. However, some coastal areas in their study displayed the opposite tendency. Macias et al. (2015) anticipated no future global changes of integrated PP in the Mediterranean Sea from modeling results. They predicted a tendency to oligotrophication in the western basin and increase in the productivity of the eastern basin. Our study reveals that $\Sigma \mathrm{PP}_{\text {Coastal }}$ in the Mediterranean Sea varies nonlinearly, and a reduction of carbon fixation rates has been observed since 2012 (Fig. 4a). Overall negative coastal PP trends are reported here in both the western and in the eastern basin $(-10.70$ and $-25.39 \mathrm{TC}$ per decade; Fig. $4 \mathrm{~b}$ and c). A spatial analysis of the longterm decadal variability reveals weak but spatially coherent and significant tendencies ( $p<0.05$; Fig. 5). In particular, PP declines along the coasts of Spain and Africa. Conversely, trends in some areas of the Adriatic Sea are markedly positive (>0.1 $\mathrm{g} \mathrm{C} \mathrm{m}^{-2}$ per decade), mainly in the proximity of the Po River. While negative tendencies seem to fit with the assumed model of PP limitation associated with increasing temperatures, the origin of the positive trend in the Adriatic basin is more uncertain. A plausible explanation is the variation in the flux and loads of the northern Adriatic rivers. For example, Giani et al. (2012) observed an increase in the Po River flow with increasing phosphate and dissolved nitrogen concentrations in the Po delta and its surrounding shelf waters. Alternatively, the Bimodal Oscillating System (BiOS), i.e., the feedback mechanism between the Adriatic 

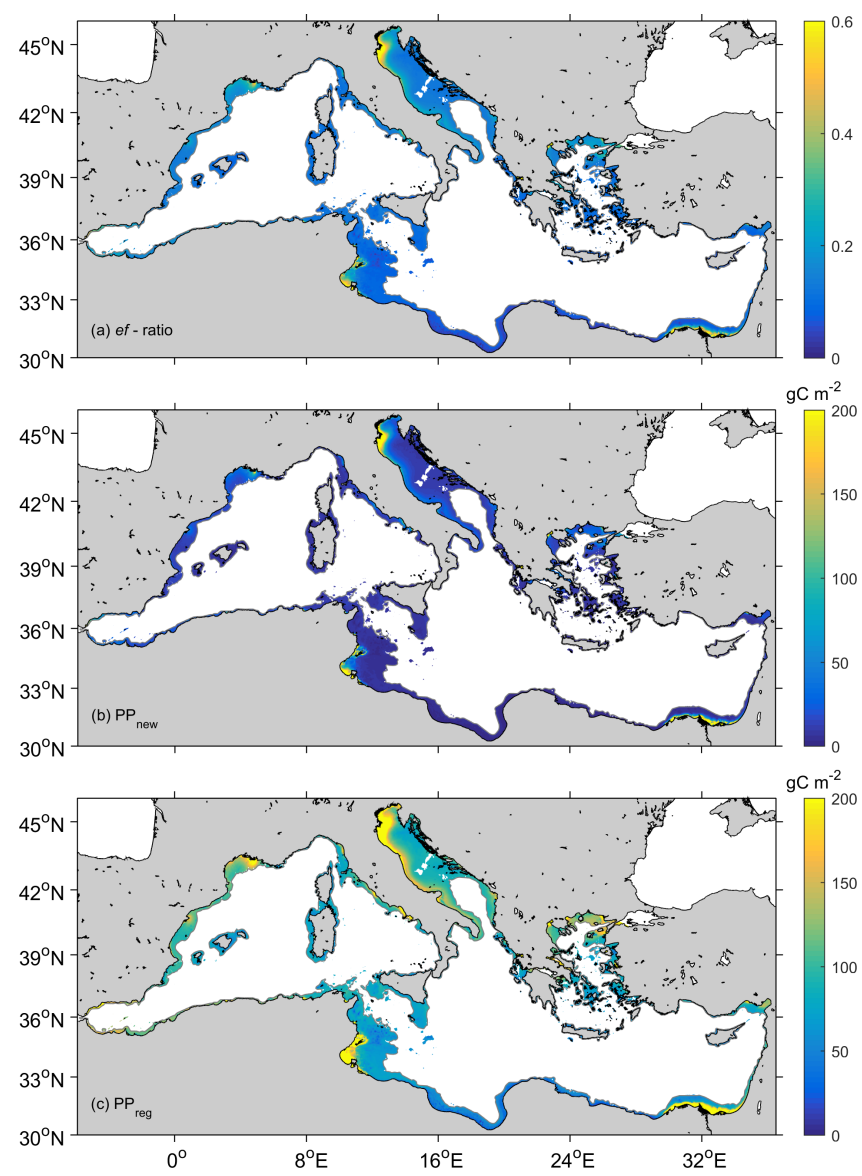

Figure 8. (a) $e$-ratio in coastal waters $(<200 \mathrm{~m})$ of the Mediterranean Sea and estimated values of $(\mathbf{b})$ new $\left(\mathrm{PP}_{\text {new }}\right)$ and $(\mathbf{c})$ regenerated production ( P $_{\text {reg }}$ ). Mean values for the period 2002-2016.

and Ionian (Civitarese et al., 2010) peaking between 2004 and 2006, could have affected mass and nutrient exchanges between the Adriatic and the north Ionian Sea (Font et al., 2007; Schroeder et al., 2008; Šolić et al., 2008; Viličić et al., 2012).

Long-term decadal variations in the eastern and western basins are mostly coupled, suggesting that they share the same PP drivers at this basin scale (Fig. $4 \mathrm{~b}$ and c). A major feature in the interannual pattern is a global decrease in production in 2012 that is extended to the following years in the eastern basin. Durrieu de Madron et al. (2013) reported peculiar atmospheric conditions in the Mediterranean Sea during 2012 that triggered a massive formation of dense water on the continental shelf and in the deep basin of the Gulf of Lion. A similar anomaly was described in the Adriatic shelf where unprecedented dense water generation was preconditioned by a dry and warm year, resulting in a significant reduction of coastal freshwaters and basin-wide salinity increase (Mihanović et al., 2013; Raicich et al., 2013b). Additionally, Pastor et al. (2018) observed an anomalous temperature increase in the Mediterranean Sea during summer
2012. From our analysis, we infer that this climate-related event had a strong influence on the global coastal PP of the Mediterranean Sea.

Several studies have reported influence of climate variations on the coast (Belgrano et al., 2008; Cloern et al., 2007; Tiselius et al., 2016). In agreement, we observed an influence of climate-scale variability on coastal productivity as suggested by the inverse correlations between $\Sigma$ PP and SST and, more loosely, by NAO and MOI (Fig. 6). While these correlations emphasize the pre-eminent role of climate variability in the regulation of interannual to decadal-scale coastal productivity, the pathways through which this control of the atmosphere over coastal productivity is exerted are complex and may regionally differ (Grbec et al., 2009). Climate can influence phytoplankton growth by the direct effect of temperature on algal metabolism, by changes in basin-scale circulation (including exchanges with adjacent seas), by regulating nutrient supply through variations in the thermocline intensity, by changes in wind patterns affecting mixing and dust deposition pathways, or through changes in precipitation that have direct influence on wet deposition and on river runoff. These effects are modulated by changes in the biota and in the interaction between organisms (e.g., Molinero et al., 2005). The relative importance of climate-driven processes relative to other productivity-enhancing processes depends on regional characteristics and may be seasonally varying. For example, variations in dust deposition, which may sustain up to $50 \%$ of new production in the Levantine basin (Kress and Herut, 2001; Herut et al., 2002), are expected to be more important on the eastern and southern Mediterranean coasts because of their proximity to the Saharan dust sources. Likewise, variations in cooling and vertical mixing are expected to be more effective during late winter when PP peaks and when diatoms dominate in the Mediterranean Sea (Lacroix and Nival, 1998; Marty, 2002; Marty and Chiavérini, 2010).

Our results reveal that, in contrast to other regions like the North Sea (Capuzzo et al., 2018) or the Arctic Ocean (Gregg et al., 2003), the coastal Mediterranean Sea did not globally display a marked decline in PP during the last decades. We suggest that in some coastal areas, a decrease in vertical nutrient supply though the thermocline may be compensated for by other nutrient sources. Variations in atmospheric deposition, groundwater and river outflows, and the influence of human activities through changes in landscape use and domestic wastewater management are important sources of nutrients in the ecosystem and thus act as major drivers of PP in these waters (e.g., Paerl et al., 1999; Powley et al., 2016). As a consequence of human activities, both terrestrial and coastal ecosystems have experienced progressive nutrient enrichment (Conley et al., 2009; Deegan et al., 2012). However, while this effect is evidenced in shallow nearshore waters, its influence in the ocean is estimated to be minimal (Wang et al., 2018). In the Mediterranean Sea, high coast population growth rates and concomitant food demand have 
resulted in a dramatic increase in water demand for irrigation farming and fertilizer use (Ryan, 2008). Indeed, while the freshwater discharge of Mediterranean rivers has significantly reduced during recent decades $(\sim 20 \%)$, the corresponding total nitrogen inputs to coastal seas are estimated to have increased by a factor of up to 5, fueling PP in riverinfluenced areas (Ludwig et al., 2009). While the importance of groundwater in the Mediterranean Sea could be comparable to that of rivers (Rodellas et al., 2015) and generalized nitrification of Mediterranean coastal aquifers is acknowledged (EEA, 1995; Zalidis et al., 2002), general trends in groundwater discharges remain largely unknown.

\subsection{Coastal regionalization}

Coastal regionalization reveals marked differences in coastal water PP in the Mediterranean Sea. Annual values range from $215 \pm 124 \mathrm{~g} \mathrm{Cm}^{-2}$ in the north Alboran Sea (Z1) to $48 \pm 17 \mathrm{~g} \mathrm{C} \mathrm{m}^{-2}$ along the coasts of Egypt and Libya (Z16). These values are globally lower than published data; yet, literature values in coastal waters are highly variable depending on methodology, depth, and/or sampling date. For example, García-Gorriz and Carr (2001) estimated annual PP of 300$900 \mathrm{~g} \mathrm{C} \mathrm{m}^{-2}$ for Z1, but Morán and Estrada (2001) narrowed this range to mean values between 121 and $366 \mathrm{~g} \mathrm{Cm}^{-2}$ depending on distance from the coast. Pugnetti et al. (2008) reported mean values of $150 \mathrm{~g} \mathrm{C} \mathrm{m}^{-2}$ that are almost 2 times higher than our values at $\mathrm{Z} 8$. In the lower range, Sournia (1973) estimated $30-60 \mathrm{~g} \mathrm{Cm}^{-2}$ in $\mathrm{Z16}$, which is in accordance with our values for this zone. In this sense, despite the limitations inherent to satellite data, the present work provides estimations based on a long data record (14 years) and a homogeneous methodology.

The nine characteristic temporal patterns obtained from the SOM analysis (Fig. 7) reveal small differences in PP among the different regions. Most variations are due to changes in the magnitude of annual carbon fixation, although seasonality varies little. Exceptions are R7, R8, and R9 which represent the dynamics in coastal regions regulated by terrestrial inputs. Likewise, interannual variations are highly coherent among regions, following the basin-scale pattern shown in Fig. 4, including the remarkable decline in productivity during 2012. Exceptions are R1, representing the dynamics in the Gulf of Sirte and R7 in the Gulf of Gabès where a different interannual variability suggests alternative sources of PP variability in this region. Indeed, the Gulf of Gabès is a region displaying consistently high chl and PP in most studies (e.g., Bosc et al., 2004; Barale et al., 2008). Drira et al. (2008) reported high biomass and toxic dinoflagellate blooms in the inner shelf of the Gulf of Gabès where surface nitrate concentration often exceeded $1 \mu \mathrm{M}$. This enrichment is associated with degradation of the water quality attributed to industrial and urban activities (Hamza-Chaffai et al., 1997; Zairi and Rouis, 1999). However, even though these waters may suffer from eutrophication, satellite-borne

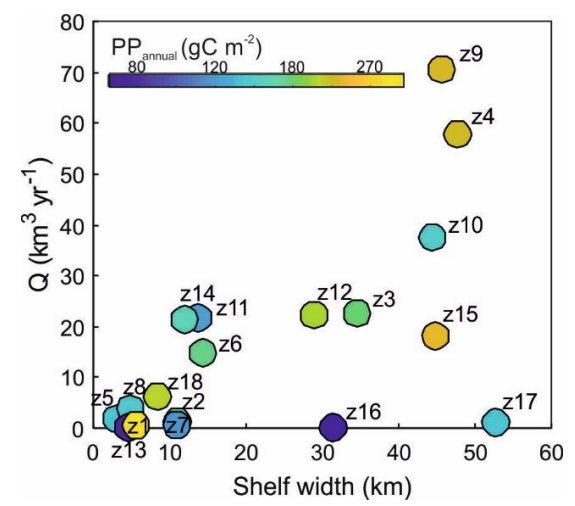

Figure 9. Relation between primary production, shelf width, and river discharge flow $(Q)$. Bubble colors indicate the $\mathrm{PP}_{\text {annual }}$ $\left(\mathrm{g} \mathrm{C}^{-2}\right)$ for each of the 18 defined zones (see Fig. 7 and Table 5).

data overestimate chl within these waters, as revealed by Katlane et al. (2011), who observed constant high turbidity and suspended matter of industrial origin affecting these waters but also reflection from the bottom affecting MODIS data. This suggests that general chl algorithms may be particularly inaccurate in this region.

The magnitude of coastal PP has often been related to both shelf width and magnitude of river discharge (Liu et al., 2010). Our data do not display a general relationship between shelf width and $\mathrm{PP}_{\text {annual }}$ (Table 5 and Fig. 9). Indeed, wide shelves with important river discharge flux from the Po, the Rhône, and the Nile rivers display high productivity ( $\mathrm{Z} 4$, $\mathrm{Z} 9$, and $\mathrm{Z15}>170 \mathrm{~g} \mathrm{Cm}^{-2}$ ) whereas production is low in the narrowest shelves like Z2, Z5, and Z16. However, $\mathrm{PP}_{\text {annual }}$ in some regions with important river inflows, like Z10, are significantly lower $\left(89 \pm 37 \mathrm{~g} \mathrm{C} \mathrm{m}^{-2}\right)$. In other regions like $\mathrm{Z} 1$ and Z8 PP is high despite the lack of important freshwater sources.

The role of river discharges depends both on $Q$ and on nutrient loads. Most Mediterranean rivers have lost their natural flows, and their discharges to the sea are strongly regulated by dams and water abstractions. Consequently, their outflow to the Mediterranean Sea is highly uncoupled from weather and climate variability. For instance, some rivers flowing into the Adriatic and Ionian seas, like the Acheloos, Nestos, or Aliákmon, today present high to maximum discharge in July due to peak hydropower production (Skoulikidis et al., 2009).

Nutrient and organic matter loads have increased globally during the last century (Beusen et al., 2016). Concentrations exported to nearby seas depend on the combined effects of lithology, urban effluents, industry, and agriculture in catchment basins that are often difficult to quantify. The land use and land cover (LULC) data collection provides indices of the threat of potential development for setting land and water quality policies. Rivers like the Rhône and Po with important influence on coastal productivity flow through extensive areas and therefore accumulate the impact from anthro- 
pogenic activities. Agricultural practices and urban effluents can strongly determine the concentration and molar ratios of the nutrients flowing into coastal waters. For example, despite the flux of the Nile River having been drastically reduced after the operation of the Aswan Dam (from 47 to $17 \mathrm{~km}^{3} \mathrm{yr}^{-1}$, Ludwig et al., 2009), the coastal region is still highly productive. A remarkable increase in the concentrations of nitrate derived from fertilizers and sewage is responsible for this sustained productivity (Turley, 1999; Nixon, 2003, 2004). Conversely, pollution pressures in the western Balkan basins are relatively low, and the Neretva (Z10), running through a karstic region in Croatia, displays low nutrient levels (Ludwig et al., 2009; Skoulikidis et al., 2009).

Finally, other oceanographic processes determine the productivity of coastal regions. In particular, Z1 and Z18 in the Alboran Sea are comparatively more productive than other areas. The influence of winds and circulation patterns favoring subsurface water upwelling and higher productivity in the northern Alboran Sea were described by García-Gorriz and Carr (2001). Also, localized patterns of relatively high primary production were found in persistent deep water density fronts resulting from the interaction of Modified Atlantic Water (MAW) and Mediterranean water by Lohrenz et al. (1988).

\section{Conclusions}

In summary, pelagic PP in coastal shelves of the Mediterranean Sea during the period 2002-2016 was estimated in this study for the first time using available satellite ocean color products. We estimated that $12 \%$ of PP of the Mediterranean Sea is attributable to coastal pelagic production, and from that about $80 \%$ of this carbon fixation is sustained by regenerated pathways. High PP spatial variations were observed among the different regions, as mainly driven by major river effluents, exchanges with nearby seas (i.e., Black Sea and the Atlantic Ocean), and local processes. Our study shows that some coastal areas are indeed highly productive $\left(>400 \mathrm{~g} \mathrm{C} \mathrm{m}^{-2}\right)$ and sustain a large percentage of overall coastal production. Indeed, their temporal variability could be of paramount importance to understand variations in higher trophic levels (e.g., Piroddi et al., 2017). Despite that temporal variability being dominated by interannual and sub-decadal variations, our analysis reveals a weak negative global PP trend in the Mediterranean Sea related to climate-driven patterns (i.e., temperature increase). Nevertheless, long-term effects can be regionally variable (i.e., PP trends in the Adriatic Sea are positive), and variations in fluvial nutrient inputs, together with other processes such as ocean warming in coastal regions, including heat waves, deserve a closer look as longer ocean color databases become available. Finally, we identify 18 along-shelf zones based on their temporal PP patterns. Two main PP groups were observed: zones with strong cross-shore gradients, typically found in wider estuarine regions, and homogeneous zones within narrow continental shelf areas. These two types of coastal waters clearly characterize the coastal area of a sea where coastal waters are otherwise strongly influenced by ocean conditions.

\section{Appendix A}
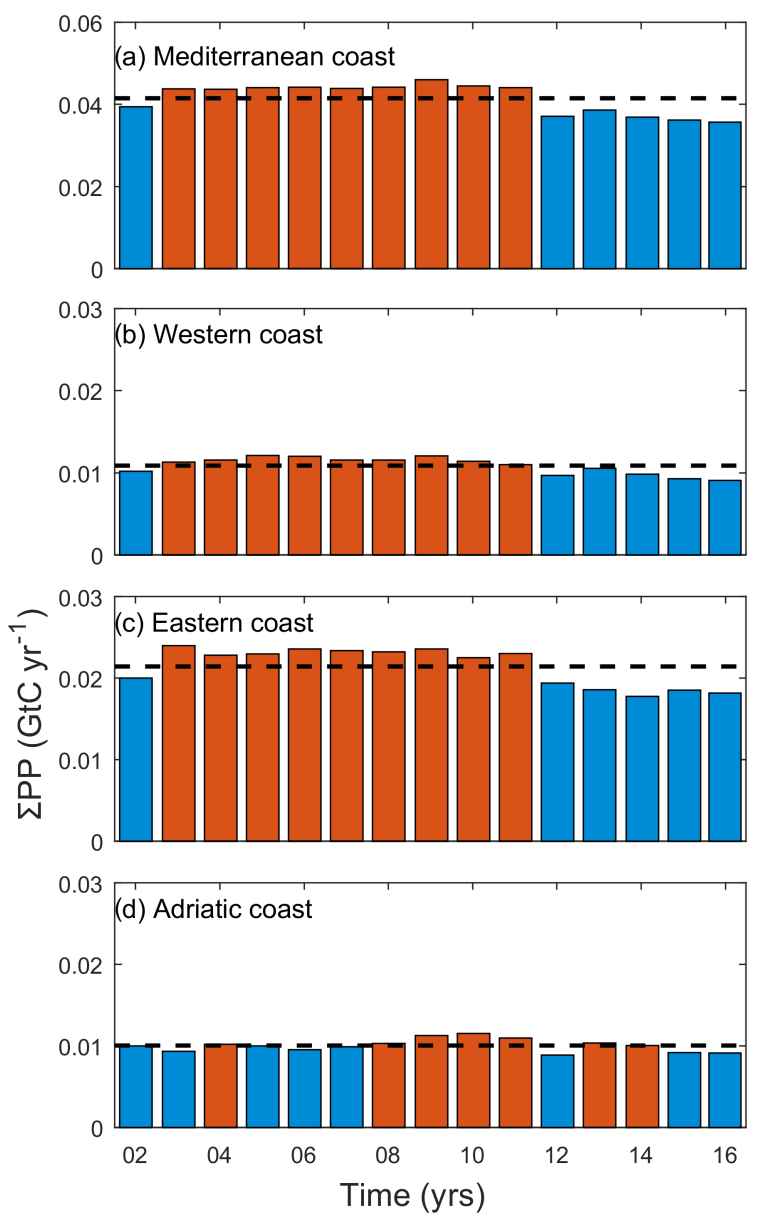

Figure A1. Annual coastal variations in $\Sigma \mathrm{PP}\left(\mathrm{GtCyr}^{-1}\right)$ for (a) the whole Mediterranean Sea, (b) the western basin, (c) the eastern basin, and (d) the Adriatic basin. Dashed black lines indicate the mean $\Sigma P_{\text {Coastal }}$ for the period 2002-2016 at each study region. Red and blue bars indicate years above and below average values, respectively. 

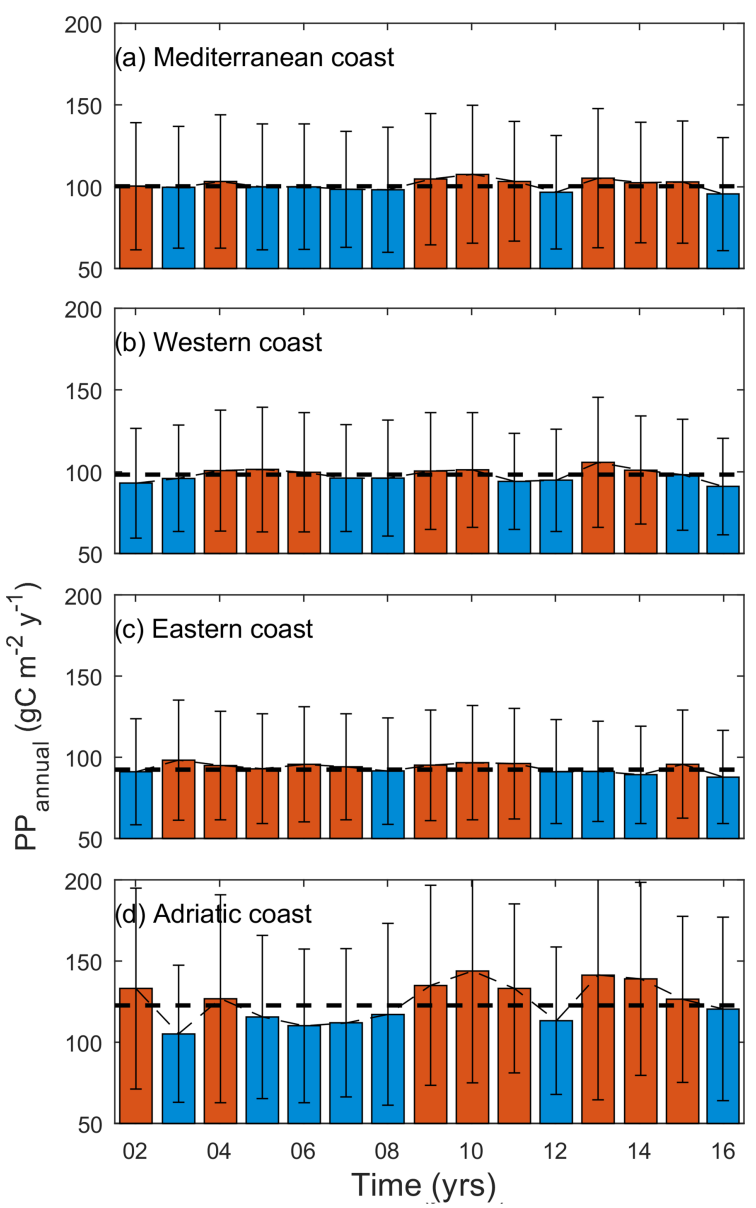

Figure A2. Annual mean coastal variations, $\mathrm{PP}_{\text {annual }}$ $\left(\mathrm{gC} \mathrm{m}^{-2} \mathrm{yr}^{-1}\right)$, for (a) the whole Mediterranean Sea, (b) the western basin, (c) the eastern basin, and (d) the Adriatic basin. Dashed black lines indicate the coastal mean $\mathrm{PP}_{\text {annual }}$ at each study region. Red and blue bars indicate years above and below average values, respectively.
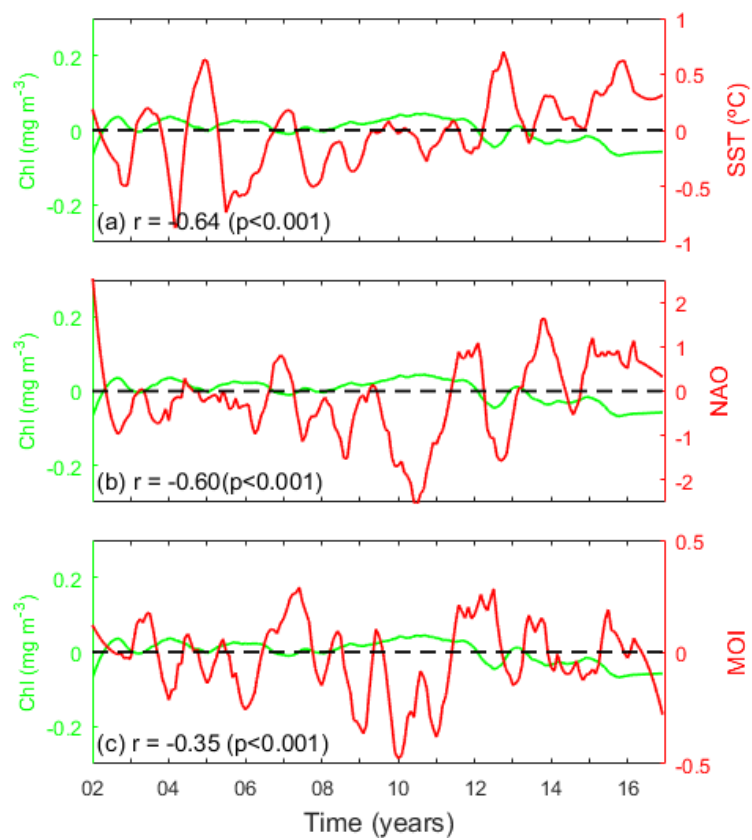

Figure A3. Relationship between coastal pelagic chlorophyll (chl anomalies, green lines) and (a) SST anomalies, (b) NAO index, and (c) MOI index (red lines).

Table A1. Correlations between yearly and seasonal total carbon fixation anomalies ( $\Sigma \mathrm{PP})$ for the coastal Mediterranean waters and its sub-basins with the climatic indices NAO and MOI.

\begin{tabular}{|c|c|c|c|c|c|c|c|c|c|c|c|}
\hline & & \multicolumn{5}{|c|}{ NAO index } & \multicolumn{5}{|c|}{ MOI index } \\
\hline & & Annual & Spring & Summer & Fall & Winter & Annual & Spring & Summer & Fall & Winter \\
\hline \multirow[t]{2}{*}{ Coastal waters } & $r$ & -0.46 & 0.02 & 0.02 & 0.00 & 0.00 & -0.24 & 0.28 & 0.02 & 0.02 & 0.02 \\
\hline & $P$ value & $<0.001$ & 0.60 & 0.58 & 0.96 & 0.97 & 0.00 & 0.04 & 0.62 & 0.63 & 0.60 \\
\hline \multirow[t]{2}{*}{ Western coast } & $r$ & -0.40 & 0.00 & 0.25 & 0.12 & 0.02 & -0.22 & 0.08 & 0.00 & 0.00 & 0.00 \\
\hline & $P$ value & $<0.001$ & 0.88 & 0.06 & 0.20 & 0.59 & 0.01 & 0.31 & 0.80 & 0.85 & 0.96 \\
\hline \multirow[t]{2}{*}{ Eastern coast } & $r$ & -0.42 & 0.02 & 0.22 & 0.02 & 0.00 & -0.11 & 0.02 & 0.02 & 0.01 & 0.04 \\
\hline & $P$ value & $<0.001$ & 0.63 & 0.08 & 0.59 & 0.89 & 0.15 & 0.62 & 0.65 & 0.71 & 0.46 \\
\hline \multirow[t]{2}{*}{ Adriatic coast } & $r$ & -0.31 & 0.03 & 0.08 & 0.00 & 0.00 & -0.38 & 0.37 & 0.01 & 0.00 & 0.01 \\
\hline & $P$ value & $<0.001$ & 0.56 & 0.30 & 0.89 & 0.89 & $<0.001$ & 0.02 & 0.74 & 0.93 & 0.70 \\
\hline
\end{tabular}


Code availability. Software codes would be available upon request to the contact author.

Data availability. Datasets and their sources are fully detailed in the manuscript. Remote sensing products and climate change indices are publicly accessible from their original providers.

Author contributions. GB, PMSH, and ARdG designed the study in collaboration with DA. PMSH and DA conducted most of the analyses. PMSH wrote the paper, with contributions from all coauthors.

Competing interests. The contact author has declared that neither they nor their co-authors have any competing interests.

Disclaimer. Publisher's note: Copernicus Publications remains neutral with regard to jurisdictional claims in published maps and institutional affiliations.

Acknowledgements. We are grateful to the National Aeronautics and Space Administration, NASA (https://oceancolour.gsfc.nasa. gov/, last access: 18 July 2017), and EU Copernicus Marine Environment Monitoring Service, CMEMS (http://marine.copernicus. eu/, last access: 2 August 2019), for the freely available oceancolor remotely sensed data. Climate indices were obtained from the Climate Research Unit at the University of East Anglia (https: //crudata.uea.ac.uk/cru/data/, last access: 21 August 2018). The authors would like to acknowledge the three anonymous reviewers and the editor Stefano Ciavatta for providing constructive and insightful comments on our paper.

Financial support. This article is a result of the Ministry of Economy and Competitiveness (MINECO) of Spain Project Fine-scale structure of cross-shore GRADIENTS along the Mediterranean coast (CTM2012-39476) and SifoMED (CTM2017-83774-P). P. M. Salgado-Hernanz was supported by a Ph.D. doctoral research fellowship FPI (Formación Personal Investigación) BES-2013-067305 from MINECO.

Review statement. This paper was edited by Stefano Ciavatta and reviewed by three anonymous referees.

\section{References}

Amante, C. and Eakins, B. W.: ETOPO1 1 Arc-Minute global relief model: Procedures, data sources and analysis, NOAA Tech. Memo. NESDIS NGDC-24, (March), 19, https://doi.org/10.1594/PANGAEA.769615, 2009.

Antoine, D. and André, M.: Algal pigment distribution and primary production in the eastern Mediterranean as derived from coastal zone color scanner observations, J. Geophys. Res., 100, 193-209, 1995.

Antoine, D. and Morel, A.: Oceanic primary production, 1. Adaptation of a spectral light-photosynthesis model in view of application to satellite chlorophyll observations, Global Biogeochem. Cy., 10, 43-55, 1996.

Antoine, D., André, J.-M. and Morel, A.: Oceanic primary production 2, Estimation at global scale from satellite (Coastal Zone Color Scanner) chlorophyll, Global Biogeochem. Cycles, 10, 57-69, https://doi.org/10.1029/95GB02832, 1996.

Barale, V., Jaquet, J. M., and Ndiaye, M.: Algal blooming patterns and anomalies in the Mediterranean Sea as derived from the SeaWiFS data set (1998-2003), Remote Sens. Environ., 112, 33003313, https://doi.org/10.1016/j.rse.2007.10.014, 2008.

Basterretxea, G., Tovar-Sanchez, A., Beck, A. J., Masqué, P., Bokuniewicz, H. J., Coffey, R., Duarte, C. M., Garcia-Orellana, J., Garcia-Solsona, E., Martinez-Ribes, L., and Vaquer-Sunyer, R.: Submarine groundwater discharge to the coastal environment of a Mediterranean island (Majorca, Spain): Ecosystem and biogeochemical significance, Ecosystems, 13, 629-643, https://doi.org/10.1007/s10021-010-9334-5, 2010.

Basterretxea, G., Font-Muñoz, J. S., Salgado-Hernanz, P. M., Arrieta, J., and Hernández-Carrasco, I.: Patterns of chlorophyll interannual variability in Mediterranean biogeographical regions, Remote Sens. Environ., 215, 7-17, https://doi.org/10.1016/j.rse.2018.05.027, 2018.

Bauer, J. E., Cai, W., Raymond, P. A., Bianchi, T. S., Hopkinson, C. S., and Regnier, P. A. G.: The changing carbon cycle of the coastal ocean, Nature, 504, 1-10, https://doi.org/10.1038/nature12857, 2013.

Behrenfeld, M. J., O’Malley, R. T., Siegel, D. A., McClain, C. R., Sarmiento, J. L., Feldman, G. C., Milligan, A. J., Falkowski, P. G., Letelier, R. M., and Boss, E. S.: Climate-driven trends in contemporary ocean productivity, Nature, 444, 752-755, https://doi.org/10.1038/nature05317, 2006.

Béjaoui, B., Ben Ismail, S., Othmani, A., Ben Abdallah-Ben Hadj Hamida, O., Chevalier, C., Feki-Sahnoun, W., Harzallah, A., Ben Hadj Hamida, N., Bouaziz, R., Dahech, S., Diaz, F., Tounsi, K., Sammari, C., Pagano, M., and Bel Hassen, M.: Synthesis review of the Gulf of Gabes (eastern Mediterranean Sea, Tunisia): Morphological, climatic, physical oceanographic, biogeochemical and fisheries features, Estuar. Coast. Shelf S., 219, 395-408, https://doi.org/10.1016/j.ecss.2019.01.006, 2019.

Belgrano, A., Lindahl, O., and Hernroth, B.: North Atlantic Oscillation primary productivity and toxic phytoplankton in the Gullmar Fjord, Sweden (1986-1996), R. Soc. Publ., 266, 425-430, 2008.

Ben Mustapha, Z., Alvain, S., Jamet, C., Loisel, H., and Dessailly, D.: Automatic classification of water-leaving radiance anomalies from global SeaWiFS imagery: Application to the detection of phytoplankton groups in open ocean waters, Remote Sens. Environ., 146, 97-112, https://doi.org/10.1016/j.rse.2013.08.046, 2014.

Berthon, J. F. and Zibordi, G.: Bio-optical relationships for the northern Adriatic Sea, Int. J. Remote Sens., 25, 1527-1532, https://doi.org/10.1080/01431160310001592544, 2004.

Bethoux, J. P.: Oxygen consumption, new production, vertical advection and environmental evolution in the Mediterranean Sea, Deep-Sea Res., 36, 769-781, https://doi.org/10.1016/01980149(89)90150-7, 1989. 
Béthoux, J. P., Morin, P., Chaumery, C., Connan, O., Gentili, B., and Ruiz-Pino, D.: Nutrients in the Mediterranean Sea, mass balance and statistical analysis of concentrations with respect to environmental change, Mar. Chem., 63, 155-169, https://doi.org/10.1016/S0304-4203(98)00059-0, 1998.

Beusen, A. H. W., Bouwman, A. F., Van Beek, L. P. H., Mogollón, J. M., and Middelburg, J. J.: Global riverine N and P transport to ocean increased during the 20th century despite increased retention along the aquatic continuum, Biogeosciences, 13, 24412451, https://doi.org/10.5194/bg-13-2441-2016, 2016.

Boldrin, A., Miserocchi, S., Rabitti, S., Turchetto, M. M., Balboni, V., and Socal, G.: Particulate matter in the southern Adriatic and Ionian Sea: Characterisation and downward fluxes, J. Marine Syst., 33-34, 389-410, https://doi.org/10.1016/S09247963(02)00068-4, 2002.

Bosc, E., Bricaud, A., and Antoine, D.: Seasonal and interannual variability in algal biomass and primary production in the Mediterranean Sea, as derived from 4 years of SeaWiFS observations, Global Biogeochem. Cy., 18, 1-17, https://doi.org/10.1029/2003gb002034, 2004.

Bricaud, A., Bosc, E., and Antoine, D.: Algal biomass and sea surface temperature in the Mediterranean Basin, Remote Sens. Environ., 81, 163-178, https://doi.org/10.1016/S00344257(01)00335-2, 2002.

Cai, W.: Estuarine and coastal ocean Carbon paradox: $\mathrm{CO}_{2}$ sinks or sites of terrestrial carbon incineration?, Annu. Rev. Mar. Sci., 3, 123-45, https://doi.org/10.1146/annurev-marine-120709142723, 2011.

Campbell, J., Antoine, D., Armstrong, R., Arrigo, K., Balch, W., Barber, R., Behrenfeld, M., Bidigare, R., Bishop, J., Carr, M., Esaias, W., Falkowski, P., Hoepffner, N., Iverson, R., Kiefer, D., Lohrenz, S., and Marra, J.: Comparison of algorithms for estimating ocean primary production from surface chlorophyll, temperature, and irradiance, Global Biochem. Cy., 16, 419-422, https://doi.org/10.1093/plankt/7.1.57, 2002.

Capuzzo, E., Lynam, C. P., Barry, J., Stephens, D., Forster, R. M., Greenwood, N., McQuatters-Gollop, A., Silva, T., van Leeuwen, S. M., and Engelhard, G. H.: A decline in primary production in the North Sea over 25 years, associated with reductions in zooplankton abundance and fish stock recruitment, Glob. Chang. Biol., 24, e352-e364, https://doi.org/10.1111/gcb.13916, 2018.

Carlson, C. A., Bates, N. R., Hansell, D. A., and Steinberg, D. K.: Carbon cycle, in Encyclopedia of Ocean Sciences, vol. 1, pp. 390-400, Elsevier Ltd., 2001.

Carr, M. E., Friedrichs, M. A. M., Schmeltz, M., Noguchi Aita, M., Antoine, D., Arrigo, K. R., Asanuma, I., Aumont, O., Barber, R., Behrenfeld, M., Bidigare, R., Buitenhuis, E. T., Campbell, J., Ciotti, A., Dierssen, H., Dowell, M., Dunne, J., Esaias, W., Gentili, B., Gregg, W., Groom, S., Hoepffner, N., Ishizaka, J., Kameda, T., Le Quéré, C., Lohrenz, S., Marra, J., Mélin, F., Moore, K., Morel, A., Reddy, T. E., Ryan, J., Scardi, M., Smyth, T., Turpie, K., Tilstone, G., Waters, K., and Yamanaka, Y.: A comparison of global estimates of marine primary production from ocean color, Deep-Sea Res. Pt. II, 53, 741-770, https://doi.org/10.1016/j.dsr2.2006.01.028, 2006.

Cebrian, J.: Variability and control of carbon consumption, export, and accumulation in marine communities, Limnol. Oceanogr., 47, 11-22, 2002.
Charantonis, A. A., Badran, F., and Thiria, S.: Retrieving the evolution of vertical profiles of Chlorophyll-a from satellite observations using Hidden Markov Models and Self-Organizing Topological Maps, Remote Sens. Environ., 163, 229-239, https://doi.org/10.1016/j.rse.2015.03.019, 2015.

Chassot, E., Bonhommeau, S., Dulvy, N. K., Mélin, F., Watson, R., Gascuel, D., and Le Pape, O.: Global marine primary production constrains fisheries catches, Ecol. Lett., 13, 495-505, https://doi.org/10.1111/j.1461-0248.2010.01443.x, 2010.

Chavez, F. P., Messi, M., and Pennington, J. T.: Marine primary production in relation to climate bariability and change, Annu. Rev. Mar. Sci., 3, 227-260, https://doi.org/10.1146/annurev.marine.010908.163917, 2011.

Civitarese, G., Gačić, M., Lipizer, M., and Eusebi Borzelli, G. L.: On the impact of the Bimodal Oscillating System (BiOS) on the biogeochemistry and biology of the Adriatic and Ionian Seas (Eastern Mediterranean), Biogeosciences, 7, 3987-3997, https://doi.org/10.5194/bg-7-3987-2010, 2010.

Cloern, J. E. and Jassby, A. D.: Complex seasonal patterns of primary producers at the land-sea interface, Ecol. Lett., 11, 12941303, https://doi.org/10.1111/j.1461-0248.2008.01244.x, 2008.

Cloern, J. E., Jassby, A. D., Thompson, J. K., and Hieb, K. A.: A cold phase of the East Pacific triggers new phytoplankton blooms in San Francisco Bay, P. Natl. Acad. Sci. USA, 104, 1856118565, https://doi.org/10.1073/pnas.0706151104, 2007.

Cole, J. J., Prairie, Y. T., Caraco, N. F., Mcdowell, W. H., Tranvik, L. J., Striegl, R. G., Duarte, C. M., Kortelainen, P., Downing, J. A., Middelburg, J. J. and Melack, J.: Plumbing the global carbon cycle: Integrating inland waters into the terrestrial carbon budget, Ecosystems, 10, 171-184, https://doi.org/10.1007/s10021006-9013-8, 2007.

Colella, S., D’Ortenzio, F., Marullo, S., Santoleri, R., Ragni, M., and D'Alcala, M. R.: Primary production variability in the Mediterranean Sea from SeaWiFS data, in: Primary production variability in the Mediterranean Sea from SeaWiFS data, vol. 5233, pp. 371-383, Proceedings of SPIE - The International Society for Optical Engineering., 2003.

Colella, S., Falcini, F., Rinaldi, E., Sammartino, M., and Santoleri, R.: Mediterranean ocean colour chlorophyll trends, PLoS One, 11, 1-16, https://doi.org/10.1371/journal.pone.0155756, 2016.

Coll, M., Piroddi, C., Steenbeek, J. G., Kaschner, K., Froglia, C., Guilhaumon, F., Coll, M., Piroddi, C., Steenbeek, J., Kaschner, K., Ben, F., Lasram, R., Ballesteros, E., Bianchi, C. N., Corbera, J., Dailianis, T., Kesner-reyes, K., Kitsos, M., Riusbarile, J., Martin, D., Mouillot, D., Oro, D., Turon, X., Villanueva, R., and Voultsiadou, E.: The biodiversity of the Mediterranean Sea: Estimates, patterns and threats, PLoS One, 5, https://doi.org/10.1371/journal.pone.0011842, 2010.

Conan, P., Pujo-Pay, M., Raimbault, P., and Leveau, M.: Variabilité hydrologique et biologique du golfe du Lion. II. Productivité sur le bord interne du courant, Oceanol. Acta, 21, 767-782, https://doi.org/10.1016/S0399-1784(99)80004-8, 1998.

Conley, D. J., Paerl, H. W., Howarth, R. W., Boesch, D. F., Seitzinger, S. P., Havens, K. E., Lancelot, C., and Likens, G. E.: Controlling Eutrophication: Nitrogen and Phosphorus, Science 323, https://doi.org/10.1126/science.1167755, 2009.

Cramer, W., Guiot, J., Fader, M., Garrabou, J., Gattuso, J. P., Iglesias, A., Lange, M. A., Lionello, P., Llasat, M. C., Paz, S., Peñuelas, J., Snoussi, M., Toreti, A., Tsimplis, M. N., and Xoplaki, 
E.: Climate change and interconnected risks to sustainable development in the Mediterranean, Nat. Clim. Chang., 8, 972-980, https://doi.org/10.1038/s41558-018-0299-2, 2018.

Criado-Aldeanueva, F. and Soto-Navarro, F. J.: The mediterranean oscillation teleconnection index: Station-based versus principal component paradigms, Adv. Meteorol., 2013, https://doi.org/10.1155/2013/738501, 2013.

Cushman-Roisin, B., Gačić, M., Poulain, P.-M. and Artegiani, A.: Physical Oceanography of the Adriatic Sea. Past, Present and Future, Kluwer Academic Publishers., 2001.

D'Alimonte, D. and Zibordi, G.: Phytoplankton determination in an optically complex coastal region using a multilayer perceptron neural network, IEEE T. Geosci. Remote, 41, 2861-2868, https://doi.org/10.1109/TGRS.2003.817682, 2003.

Deegan, L. A., Johnson, D. S., Warren, R. S., Peterson, B. J., Fleeger, J. W., Fagherazzi, S., and Wollheim, W. M.: Coastal eutrophication as a driver of salt marsh loss, Nature, 490, 388-392, https://doi.org/10.1038/nature11533, 2012.

Djakovac, T., Degobbis, D., Supic, N., Precali, R., Supić, N., and Precali, R.: Marked reduction of eutrophication pressure in the northeastern Adriatic in the period 2000-2009, Estuar. Coast. Shelf S., 115, 25-32, https://doi.org/10.1016/j.ecss.2012.03.029, 2012.

Drira, Z., Hamza, A., Belhassen, M., and Ayadi, H.: Dynamics of dinoflagellates and environmental factors during the summer in the Gulf of Gabes (Tunisia, Eastern Mediterranean Sea), Sci. Mar., 72, 59-71, 2008.

Ducklow, H. W., Steinberg, D. K., and Buesseler, K. O.: Upper ocean carbon export and the Biological Pump, Oceanography, 14, 50-58, 2001.

Ducklow, H. and McCallister, S. L.: The biogeochemistry of carbon dioxide in the coastal oceans, in The sea, Harvard University Press, 13, 269-315, 2004

Dunne, J. P., Sarmiento, J. L., and Gnanadesikan, A.: A synthesis of global particle export from the surface ocean and cycling through the ocean interior and on the seafloor, Global Biochem. Cy., 21, 1-16, https://doi.org/10.1029/2006GB002907, 2007.

Durrieu De Madron, X., Houpert, L., Puig, P., Sanchez-Vidal, A., Testor, P., Bosse, A., Estournel, C., Somot, S., Bourrin, F., Bouin, M. N., Beauverger, M., Beguery, L., Calafat, A., Canals, M., Cassou, C., Coppola, L., Dausse, D., D’Ortenzio, F., Font, J., Heussner, S., Kunesch, S., Lefevre, D., Le Goff, H., Martín, J., Mortier, L., Palanques, A., and Raimbault, P.: Interaction of dense shelf water cascading and open-sea convection in the northwestern Mediterranean during winter 2012, Geophys. Res. Lett., 40, 1379-1385, https://doi.org/10.1002/grl.50331, 2013.

EEA: Europe's Environment - The Dobris Assessment, available from: https://www.eea.europa.eu/publications/92-826-5409-5 (last access: 1 October 2020), 1995.

Efthymiadis, D., Goodess, C. M., and Jones, P. D.: Trends in Mediterranean gridded temperature extremes and large-scale circulation influences, Nat. Hazards Earth Syst. Sci., 11, 21992214, https://doi.org/10.5194/nhess-11-2199-2011, 2011.

Estrada, M.: Primary production in the northwestern Mediterranean, Sci. Mar., 60, 55-64, 1996.

Farikou, O., Sawadogo, S., Niang, A., Diouf, D., Brajard, J., Mejia, C., Dandonneau, Y., Gasc, G., Crepon, M., and Thiria, S.: Inferring the seasonal evolution of phytoplankton groups in the Senegalo-Mauritanian upwelling region from satellite ocean- color spectral measurements, J. Geophys. Res.-Oceans, 120, 6581-6601, https://doi.org/10.1002/2015JC010738, 2015.

Field, C. B., Behrenfeld, M. J. and Randerson, J. T.: Primary Production of the biosphere: Integrating terrestrial and oceanic components, Science, 281, 237-240, https://doi.org/10.1126/science.281.5374.237, 1998.

Friedrichs, M. A. M., Carr, M., Barber, R. T., Scardi, M., Antoine, D., Armstrong, R. A., Asanuma, I., Behrenfeld, M. J., Buitenhuis, E. T., Chai, F., Christian, J. R., Ciotti, A. M., Doney, S. C., Dowell, M., Dunne, J., Gentili, B., Gregg, W., Hoepffner, N., Ishizaka, J., Kameda, T., Lima, I., Marra, J., Mélin, F., Moore, J. K., Morel, A., Malley, R. T. O., Reilly, J. O., Saba, V. S., Schmeltz, M., Smyth, T. J., Tjiputra, J., Waters, K., Westberry, T. K., and Winguth, A.: Assessing the uncertainties of model estimates of primary productivity in the tropical Pacific Ocean, J. Marine Syst., 76, 113-133, https://doi.org/10.1016/j.jmarsys.2008.05.010, 2009.

Font, J., Puig, P., Salat, J., Palanques, A., and Emelianov, M.: Sequence of hydrographic changes in NW mediterranean deep water due to the exceptional winter of 2005, Sci. Mar., 71, 339-346, https://doi.org/10.3989/scimar.2007.71n2339, 2007.

Garcia-gorriz, E. and Carr, M. E.: Physical control of phytoplankton distributions in the Alboran Sea: A numerical and satellite approach, J. Geophys. Res.-Oceans, 106, 16795-16805, https://doi.org/10.1029/1999jc000029, 2001.

Gasol, J. M., Cardelús, C., Morán, X. A. G., Balagué, V., Forn, I., Marrasé, C., Massana, R., Pedrós-Alió, C., Sala, M. M., Simó, R., Vaqué, D., and Estrada, M.: Seasonal patterns in phytoplankton photosynthetic parameters and primary production at a coastal NW Mediterranean site | Regularidades estacionales en la producción primaria y los parámetros fotosintéticos en una estación costera del NO Mediterráneo, Sci. Mar., 80, 63-77, https://doi.org/10.3989/scimar.04480.06E, 2016.

Gattuso, J. P., Frankignoulle, M., and Wollast, R.: Carbon and carbonate metabolism in coastal aquatic ecosystems, Annu. Rev. Ecol. Syst., 29, 405-434, https://doi.org/10.1146/annurev.ecolsys.29.1.405, 1998.

Giani, M., Djakovac, T., Degobbis, D., Cozzi, S., Solidoro, C., and Umani, S. F.: Recent changes in the marine ecosystems of the northern Adriatic Sea, Estuar. Coast. Shelf S., 115, 1-13, https://doi.org/10.1016/j.ecss.2012.08.023, 2012.

Goffart, A., Hecq, J. H., and Legendre, L.: Changes in the development of the winter-spring phytoplankton bloom in the Bay of Calvi (NW Mediterranean) over the last two decades: A response to changing climate?, Mar. Ecol. Prog. Ser., 236, 45-60, https://doi.org/10.3354/meps236045, 2002.

Grbec, B., Morović, M., Beg Paklar, G., Kušpilić, G., Matijević, S., Matić, F., and Gladan, Ž. N.: The relationship between the atmospheric variability and productivity in the adriatic Sea area, J. Mar. Biol. Assoc. UK, 89, 1549-1558, https://doi.org/10.1017/S0025315409000708, 2009.

Gregg, W. W., Conkright, M. E., Ginoux, P., O'Reilly, J. E., and Casey, N. W.: Ocean primary production and climate: Global decadal changes, Geophys. Res. Lett., 30, 10-13, https://doi.org/10.1029/2003GL016889, 2003.

Hamza-Chaffai, A., Amiard-Triquet, C., and El Abed, A.: Metallothionein-like protein: Is it an efficient biomarker of metal contamination? A case study based on fish from 
the Tunisian coast, Arch. Environ. Con. Tox., 33, 53-62, https://doi.org/10.1007/s002449900223, 1997.

Hernández-Carrasco, I. and Orfila, A.: The Role of an Intense Front on the Connectivity of the Western Mediterranean Sea: The Cartagena-Tenes Front, J. Geophys. Res. Ocean., 123, 43984422, https://doi.org/10.1029/2017JC013613, 2018.

Henson, S. A., Sarmiento, J. L., Dunne, J. P., Bopp, L., Lima, I., Doney, S. C., John, J., and Beaulieu, C.: Detection of anthropogenic climate change in satellite records of ocean chlorophyll and productivity, Biogeosciences, 7, 621-640, https://doi.org/10.5194/bg-7-621-2010, 2010.

Herut, B., Collier, R., and Krom, M. D.: The role of dust in supplying nitrogen and phosphorus to the Southeast Mediterranean, Limnol. Oceanogr., 47, 870-878, https://doi.org/10.4319/1o.2002.47.3.0870, 2002.

Hurrell, J. W.: Decadal trends in the North Atlantic Oscillation: Regional temperatures and precipitation, Science, 269, 7-10, 1995.

Hurrell, J. W. and Van Loon, H.: Decadal variations in climate associated with the North Atlantic oscillation, Clim. Change, 36, 301-326, https://doi.org/10.1023/a:1005314315270, 1997.

Kahru, M., Brotas, V., Manzano-Sarabia, M., and Mitchell, B. G.: Are phytoplankton blooms occurring earlier in the Arctic?, Glob. Change Biol., 17, 1733-1739, https://doi.org/10.1111/j.13652486.2010.02312.x, 2011.

Katlane, R., Nechad, B., Ruddick, K., and Zargouni, F.: Optical remote sensing of turbidity and total suspended matter in the Gulf of Gabes, Arab. J. Geosci., 6, 1527-1535, https://doi.org/10.1007/s12517-011-0438-9, 2011.

Kohonen, T.: Self-organized Formation of topologically correct feature maps, Biol. Cybern., 43, 59-69, https://doi.org/10.1007/BF00337288, 1982.

Kohonen, T.: Self-Organizing Maps, Springer-Verlag Berlin Heidelbergh, Berlin Heidelberg, 2001.

Kress, N. and Herut, B.: Spatial and seasonal evolution of dissolved oxygen and nutrients in the Southern Levantine Basin (Eastern Mediterranean Sea): Chemical characterization of the water masses and inferences on the N: P ratios, Deep-Sea Res. Pt. I, 48, 2347-2372, https://doi.org/10.1016/S0967-0637(01)00022X, 2001.

Lacroix, G. and Nival, P.: Influence of meteorological variability on primary production dynamics in the Ligurian Sea (NW Mediterranean Sea) with a 1D hydrodynamic/biological model, J. Marine Syst., 16, 23-50, https://doi.org/10.1016/S0924-7963(97)000985, 1998.

Laws, E. A., Falkowski, P. G., Smith, W. O., Ducklow, H., and McCarthy, J. J.: Temperature effects on export production in the open ocean, Global Biogeochem. Cy., 14, 1231-1246, https://doi.org/10.1029/1999GB001229, 2000.

Laws, E. A., D'Sa, E., and Naik, P.: Simple equations to estimate ratios of new or export production to total production from satellite-derived estimates of sea surface temperature and primary production, Limnol. Oceanogr.-Meth., 9, 593-601, https://doi.org/10.4319/lom.2011.9.593, 2011.

Lazzari, P., Solidoro, C., Ibello, V., Salon, S., Teruzzi, A., Béranger, K., Colella, S., and Crise, A.: Seasonal and inter-annual variability of plankton chlorophyll and primary production in the Mediterranean Sea: a modelling approach, Biogeosciences, 9, 217-233, https://doi.org/10.5194/bg-9-217-2012, 2012.
Lionello, P. and Scarascia, L.: The relation between climate change in the Mediterranean region and global warming, Reg. Environ. Change, 18, 1481-1493, https://doi.org/10.1007/s10113018-1290-1, 2018.

Liu, K.-K., Iseki, K., and Chao, Y.: Continental margin carbon fluxes, in The Changing Ocean Carbon Cycle: A Midterm Synthesis of the Joint Global Ocean Flux Study, Hanson, R. B., Ducklow, H. W., and Field, J. G. (Eds.), Cambridge University Press., 2000.

Liu, Y. and Weisberg, R. H.: Patterns of ocean current variability on the West Florida Shelf using the self-organizing map, J. Geophys. Res.-Oceans, 110, 1-12, https://doi.org/10.1029/2004JC002786, 2005.

Liu, Y., Weisberg, R. H. H., and Mooers, C. N. K. N. K.: Performance evaluation of the self-organizing map for feature extraction, J. Geophys. Res.-Oceans, 111, 1-14, https://doi.org/10.1029/2005JC003117, 2006.

Liu, K.-K., Atkinson, L., Quiñones, R. A., and Talaue-McManus, L.: Biogeochemistry of continental margins in a global context, in Carbon and Nutrient Fluxes in Continental Margins, GlobalChange - The IGBP Series, Springer-Verlag, 2010.

Lohrenz, S. E., Wiesenburg, D. A., DePalma, I. P., Johnson, K. S., and Gustafson, D. E.: Interrelationships among primary production, chlorophyll, and environmental conditions in frontal regions of the western Mediterranean Sea, Deep-Sea Res., 35, 793-810, https://doi.org/10.1016/0198-0149(88)90031-3, 1988.

Ludwig, W., Dumont, E., Meybeck, M., and Heussner, S.: River discharges of water and nutrients to the Mediterranean and Black Sea: Major drivers for ecosystem changes during past and future decades?, Prog. Oceanogr., 80, 199-217, https://doi.org/10.1016/j.pocean.2009.02.001, 2009.

Macias, D. M., Garcia-Gorriz, E., and Stips, A.: Productivity changes in the Mediterranean Sea for the twenty-first century in response to changes in the regional atmospheric forcing, Front. Mar. Sci., 2, 1-13, https://doi.org/10.3389/fmars.2015.00079, 2015.

Macias, D., Garcia-Gorriz, E., and Stips, A.: Major fertilization sources and mechanisms for Mediterranean Sea coastal ecosystems, Limnol. Oceanogr., 63, 897-914, https://doi.org/10.1002/lno.10677, 2017.

Marshall, J., Kushnir, Y., Battisti, D., Chang, P., Czaja, A., Dickson, R., Hurrell, J., McCartney, M., Saravanan, R., Visbeck, M., Robert, D., Hurrel, J., McCartney, M., Saravanan, R., and Visbeck, M.: Review: North Atlantic climate variability: Phenomena, impacts and mechanisms, Int. J. Climatol., 21, 1863-1898, https://doi.org/10.1002/joc.693, 2001.

Martínez-Asensio, A., Marcos, M., Tsimplis, M. N., Gomis, D., Josey, S., and Jordà, G.: Impact of the atmospheric climate modes on Mediterranean sea level variability, Global Planet Change, 118, 1-15, https://doi.org/10.1016/j.gloplacha.2014.03.007, 2014.

Marty, J. C.: The DYFAMED time-series program (French-JGOFS), Deep-Sea Res. Pt. II, 49, 1963-1964, https://doi.org/10.1016/S0967-0645(02)00021-8, 2002.

Marty, J. C. and Chiavérini, J.: Hydrological changes in the Ligurian Sea (NW Mediterranean, DYFAMED site) during 1995-2007 and biogeochemical consequences, Biogeosciences, 7, 21172128, https://doi.org/10.5194/bg-7-2117-2010, 2010. 
Marty, J. C., Chiavérini, J., Pizay, M. D., and Avril, B.: Seasonal and interannual dynamics of nutrients and phytoplankton pigments in the western Mediterranean Sea at the DYFAMED timeseries station (1991-1999), Deep-Sea Res. Pt. II, 49, 1965-1985, https://doi.org/10.1016/S0967-0645(02)00022-X, 2002.

Massey, F. J., Frank, J., and Maseey, J.: The Kolmogorov-Smirnov Test for Goodness of Fit, J. Am. Stat. Assoc., 46, 68-78, https://doi.org/10.1016/0378-3758(90)90051-U, 1951.

Micheli, F., Halpern, B. S., Walbridge, S., Ciriaco, S., Ferretti, F., Fraschetti, S., Lewison, R., Nykjaer, L., and Rosenberg, A. A.: Cumulative human impacts on Mediterranean and Black Sea marine ecosystems: Assessing current pressures and opportunities, PLoS One, 8, e79889, https://doi.org/10.1371/journal.pone.0079889, 2013.

Mihanović, H., Vilibić, I., Carniel, S., Tudor, M., Russo, A., Bergamasco, A., Bubić, N., Ljubešić, Z., Viličić, D., Boldrin, A., Malačič, V., Celio, M., Comici, C., and Raicich, F.: Exceptional dense water formation on the Adriatic shelf in the winter of 2012, Ocean Sci., 9, 561-572, https://doi.org/10.5194/os-9-561-2013, 2013.

Molinero, J. C., Ibanez, F., Nival, P., Buecher, E., and Souissi, S.: North Atlantic climate and northwestern Mediterranean plankton variability, Limnol. Oceanogr., 50, 1213-1220, https://doi.org/10.4319/lo.2005.50.4.1213, 2005.

Morán, X. A. G. and Estrada, M.: Short-term variability of photosynthetic parameters and particulate and dissolved primary production in the Alboran sea (SW Mediterranean), Mar. Ecol. Prog. Ser., 212, 53-67, https://doi.org/10.3354/meps212053, 2001.

Morel, A.: Light and marine photosynthesis: a spectral model with geochemical and climatological implications, Prog. Oceanogr., 26, 263-306, https://doi.org/10.1016/0079-6611(91)90004-6, 1991.

Morel, A. and André, J.-M.: Pigment distribution and primary production in the Western Mediterranean as derived and modeled from Coastal Zone Color Scanner Observations, J. Geophys. Res., 96, 685-698, https://doi.org/10.1029/95JC00466, 1991.

Morel, A. and Berthon, J.-F.: Surface pigments, algal biomass profiles, and potential production of the euphotic layer: Relationships reinvestigated in view of remotesensing applications, Limnol. Oceanogr., 34, 1545-1562, https://doi.org/10.4319/1o.1989.34.8.1545, 1989.

Morel, A. and Maritorena, S.: Bio-optical properties of oceanic waters: A reappraisal, J. Geophys. Res.-Oceans, 106, 7163-7180, https://doi.org/10.1029/2000jc000319, 2001.

Morel, A., Antoine, D., Babin, M., and Dandonneau, Y.: Measured and modeled primary production in the northeast Atlantic (EUMELI JGOFS program): The impact of natural variations in photosynthetic parameters on model predictive skill, DeepSea Res. Pt. I, 43, 1273-1304, https://doi.org/10.1016/09670637(96)00059-3, 1996.

Morel, A., Gentili, B., Chami, M., and Ras, J.: Bio-optical properties of high chlorophyll Case 1 waters and of yellow-substancedominated Case 2 waters, Deep-Sea Res. Pt. I, 53, 1439-1459, https://doi.org/10.1016/j.dsr.2006.07.007, 2006.

Moutin, T. and Raimbault, P.: Primary production, carbon export and nutrients availability in western and eastern Mediterranean Sea in early summer 1996 (MINOS cruise), J. Marine Syst., 33-34, 273-288, https://doi.org/10.1016/S0924-7963(02)000623, 2002.
Muller-Karger, F. E., Varela, R., Thunell, R., Luerssen, R., Hu, C., and Walsh, J. J.: The importance of continental margins in the global carbon cycle, Geophys. Res. Lett., 32, 10-13, https://doi.org/10.1029/2004GL021346, 2005.

Nixon, S. W.: Replacing the Nile: Are anthropogenic nutrients providing the fertility once brought to the Mediterranean by a great river?, Ambio A J. Hum. Environ., 32, 30-39, https://doi.org/10.1579/0044-7447-32.1.30, 2003.

Nixon, S. W.: The Artificial Nile: The Aswan High Dam blocked and diverted nutrients and destroyed a Mediterranean fishery, but human activities may have revived it, Am. Sci., 92, 158-165, 2004.

Nykjaer, L.: Mediterranean Sea surface warming 1985-2006, Clim. Res., 39, 11-17, https://doi.org/10.3354/cr00794, 2009.

O'Reilly, J. and Sherman, K.: Chapter 5.1. Primary productivity patterns and trends, United Nations Environment Programme, Nairobi, 2016.

Pace, M. L., Knauer, G. A., Karl, D. M., and Martin, J. H.: Primary production, new production and vertical flux in the eastern Pacific Ocean, Nature, 325, 803-804, https://doi.org/10.1038/325803a0, 1987.

Paerl, H. w., Willey, J. D., Go, M., Peierls, B. L., Pinckney, J. L., and Fogel, M. L.: Rainfall stimulation of primary production in western Atlantic Ocean waters: roles of different nitrogen sources and CO-limiting nutrients, Mar. Ecol. Prog. Ser., 176, 205-214, 1999.

Palutikof, J.: Analysis of Mediterranean Climate Data: Measured and Modelled, in Mediterranean Climate: Variability and Trends, H. J. Bolle (Ed.), 125-132, Springer-Verlag, Berlin, Heidelberg, 2003.

Pastor, F., Valiente, J. A. and Palau, J. L.: Sea Surface Temperature in the Mediterranean: Trends and Spatial Patterns (1982-2016), Pure Appl. Geophys., 175, 4017-4029, https://doi.org/10.1007/s00024-017-1739-z, 2017.

Pauly, D. and Christensen, V.: Primary production required to sustain global fisheries, Lett. to Nat., 374, 255-257, 1995.

Pauly, D., Christensen, V., Guénette, S., Pitcher, T. J., Sumaila, U. R., Walters, C. J., Watson, R., and Zeller, D.: Towards sustainability in world fisheries, Nat. Publ. Gr., 418, 689-695, 2002.

Pinardi, N., Zavatarelli, M., Arneri, E., Crise, A., and Ravaioli, M.: Chapter 32. The physical, sedimentary and ecological structure and variability of shelf areas in the Mediterranean Sea (27,S), in: The Sea. The Global Coastal Ocean, vol. 14, Robinson, A. R. and Brink, K. H. (Eds.), pp. 1243-1272., 2006.

Piroddi, C., Coll, M., Liquete, C., Macias, D., Greer, K., Buszowski, J., Steenbeek, J., Danovaro, R., and Christensen, V.: Historical changes of the Mediterranean Sea ecosystem: Modelling the role and impact of primary productivity and fisheries changes over time, Sci. Rep., 7, 1-18, https://doi.org/10.1038/srep44491, 2017.

Powley, H. R., Dürr, H. H., Lima, A. T., Krom, M. D., and Van Cappellen, P.: Direct Discharges of Domestic Wastewater are a Major Source of Phosphorus and Nitrogen to the Mediterranean Sea, Environ. Sci. Technol., 50, 8722-8730, https://doi.org/10.1021/acs.est.6b01742, 2016.

Pugnetti, A., Bazzoni, A. M., Beran, A., Bernardi Aubry, F., Camatti, E., Celussi, M., Coppola, J., Crevatin, E., Del Negro, P., and Paoli, A.: Changes in biomass structure and trophic status of the plankton communities in a highly dynamic ecosystem 
(Gulf of Venice, Northern Adriatic Sea), Mar. Ecol., 29, 367374, https://doi.org/10.1111/j.1439-0485.2008.00237.x, 2008.

Rahav, E., Herut, B., Levi, A., Mulholland, M. R., and BermanFrank, I.: Springtime contribution of dinitrogen fixation to primary production across the Mediterranean Sea, Ocean Sci., 9, 489-498, https://doi.org/10.5194/os-9-489-2013, 2013.

Raicich, F., Malacic, V., Celio, M., Giaiotti, D., Cantoni, C., Colucci, R. R., Cermelj, B., and Pucillo, A.: Extreme air-sea interactions in the Gulf of Trieste (North Adriatic) during the strong Bora event in winter 2012, J. Geophys. Res.-Oceans, 118, 5238-5250, https://doi.org/10.1002/jgrc.20398, 2013a.

Raicich, F., Malačič, V., Celio, M., Giaiotti, D., Cantoni, C., Colucci, R. R., Čermelj, B., and Pucillo, A.: Extreme air-sea interactions in the Gulf of Trieste (North Adriatic) during the strong Bora event in winter 2012, J. Geophys. Res.-Oceans, 118, 5238-5250, https://doi.org/10.1002/jgrc.20398, 2013b.

Regaudie-de-Gioux, A., Vaquer-Sunyer, R., and Duarte, C. M.: Patterns in planktonic metabolism in the Mediterranean Sea, Biogeosciences, 6, 3081-3089, https://doi.org/10.5194/bg-6-30812009, 2009.

Rodellas, V., Garcia-Orellana, J., Masqué, P., Feldman, M., Weinstein, Y., and Boyle, E. A.: Submarine groundwater discharge as a major source of nutrients to the Mediterranean Sea, P. Natl. Acad. Sci. USA, 112, 3926-3930, https://doi.org/10.1073/pnas.1419049112, 2015.

Ryan, J.: Crop nutrients for sustainable agricultural production in the drought-stressed mediterranean region, J. Agric. Sci. Technol., 10, 295-306, 2008.

Saba, V. S., Friedrichs, M. A. M., Antoine, D., Armstrong, R. A., Asanuma, I., Behrenfeld, M. J., Ciotti, A. M., Dowell, M., Hoepffner, N., Hyde, K. J. W., Ishizaka, J., Kameda, T., Marra, J., Mélin, F., Morel, A., O’Reilly, J., Scardi, M., Smith Jr., W. O., Smyth, T. J., Tang, S., Uitz, J., Waters, K., and Westberry, T. K.: An evaluation of ocean color model estimates of marine primary productivity in coastal and pelagic regions across the globe, Biogeosciences, 8, 489-503, https://doi.org/10.5194/bg8-489-2011, 2011.

Salgado-Hernanz, P. M., Racault, M. F., Font-Muñoz, J. S., and Basterretxea, G.: Trends in phytoplankton phenology in the Mediterranean Sea based on ocean-colour remote sensing, Remote Sens. Environ., 221, 50-64, https://doi.org/10.1016/j.rse.2018.10.036, 2019.

Salmi, T., Maatta, A., Anttila, P., Ruoho-Airola, T., and Amnell, T.: Detecting Trends of Annual Values of Atmospheric Pollutants by the Mann-Kendall Test and Sen's Solpe Estimates the Excel Template Application MAKESENS, 2002.

Schroeder, K., Ribotti, A., Borghini, M., Sorgente, R., Perilli, A., and Gasparini, G. P.: An extensive western Mediterranean deep water renewal between 2004 and 2006, Geophys. Res. Lett., 35, 1-7, https://doi.org/10.1029/2008GL035146, 2008.

Sen, P. K.: Estimates of the regression coefficient based on Kendall 's Tau Pranab Kumar Sen, J. Am. Stat. Assoc., 63, 1379-1389, 1968.

Simpson, J. H.: Physical processes in the ROFI regime, J. Marine Syst., 12, 3-15, https://doi.org/10.1016/S0924-7963(96)00085$1,1997$.

Skoulikidis, N. T., Economou, A. N., Gritzalis, K. C., and Zogaris, S.: Rivers of the Balkans, in Rivers of Europe, 421-466, Elsevier Ltd., 2009.
Smith, S. V. and Hollibaugh, J. T.: Coastal Metabolism and the Oceanic Organic Carbon Balance, Rev. Geophys., 31, 75-89, 1993.

ŠoliŠ, M., Krstulović, N., VilibiŠ, I., KušpiliŠ, G., ŠŠestanoviŠ, S., Šanti'c, D., and Ordulj, M.: The role of water mass dynamics in controlling bacterial abundance and production in the middle Adriatic Sea, Mar. Environ. Res., 65, 388-404, https://doi.org/10.1016/j.marenvres.2008.01.004, 2008.

Sournia, A.: La production primaire planctonique en Méditerranée: Essai de mise à jour. Bulletin Etude en Commun de la Méditerranée, 5, 128pp., 1973.

Stambler, N.: The Mediterranean Sea - Primary Productivity, in: The Mediterranean Sea: Its history and present challenges, Goffredo, S. and Dubinsky, Z., (Eds.), pp. 113-121, Springer, 2014.

Tiselius, P., Belgrano, A., Andersson, L., and Lindahl, O.: Primary productivity in a coastal ecosystem: A trophic perspective on a long-term time series, J. Plankton Res., 38, 1092-1102, https://doi.org/10.1093/plankt/fbv094, 2016.

Tockner, K., Uehlinger, U., and Robinson, C.: Rivers of Europe, 1st ed., Academic Press, Elsevier., 2008.

Törnros, T.: On the relationship between the Mediterranean Oscillation and winter precipitation in the Southern Levant, Atmos. Sci. Lett., 14, 287-293, https://doi.org/10.1002/asl2.450, 2013.

Tovar-Sánchez, A., Basterretxea, G., Rodellas, V., Sánchez-Quiles, D., García-Orellana, J., Masqué, P., Jordi, A., López, J. M., and Garcia-Solsona, E.: Contribution of groundwater discharge to the coastal dissolved nutrients and trace metal concentrations in Majorca Island: Karstic vs. detrital systems, Environ. Sci. Technol., 48, 11819-11827, https://doi.org/10.1021/es502958t, 2014.

Tovar-Sánchez, A., Basterretxea, G., Ben Omar, M., Jordi, A., Sánchez-Quiles, D., Makhani, M., Mouna, D., Muya, C., and Anglès, S.: Nutrients, trace metals and B-vitamin composition of the Moulouya River: A major North African river discharging into the Mediterranean Sea, Estuar. Coast. Shelf S., 176, 47-57, https://doi.org/10.1016/j.ecss.2016.04.006, 2016.

Trigo, R., Xoplaki, E., Zorita, E., Luterbacher, J., Krichak, S. O., Alpert, P., Jucundus, J., Sáens, J., Fernández, J., GonzálezRouco, F., Garcia-Herrera, R., Rodo, X., Brunetti, M., Nanni, T., Maugeri, M., Türkes, M., Gimeno, L., Ribera, P., Brunet, M., Trigo, I. F., Crepon, M., and Mariotti, A.: Relations between Variability in the Mediterranean Region and Mid-Latitude Variability, in: Developements in Earth and Environmental Sciences: Mediterranean., Lionello, P. , Malanotte-Rizzoli, P., and Boscolo, R., (Eds.), 179-226, Elsevier., 2006.

Turley, C. M.: The changing Mediterranean Sea - A sensitive ecosystem?, Prog. Oceanogr., 44, 387-400, https://doi.org/10.1016/S0079-6611(99)00033-6, 1999.

Uitz, J., Claustre, H., Morel, A., and Hooker, S. B.: Vertical distribution of phytoplankton communities in open ocean: An assessment based on surface chlorophyll, J. Geophys. Res. Ocean., 111, 1-23, https://doi.org/10.1029/2005JC003207, 2006.

Uitz, J., Claustre, H., Gentili, B., and Stramski, D.: Phytoplankton class-specific primary production in the world's oceans: Seasonal and interannual variability from satellite observations, Global Biogeochem. Cy., 24, 1-19, https://doi.org/10.1029/2009GB003680, 2010.

Umani, S. F.: Pelagic production and biomass in the Adriatic Sea, Sci. Mar., 60, 65-77, 1996. 
Umani, S. F., Del Negro, P., Larato, C., De Vittor, C., Cabrini, M., Celio, M., Falconi, C., Tamberlich, F., and Azam, F.: Major interannual variations in microbial dynamics in the Gulf of Trieste (northern Adriatic Sea) and their ecosystem implications, Aquat. Microb. Ecol., 46, 163-175, https://doi.org/10.3354/ame046163, 2007.

Van Wambeke, F., Lefèvre, D., Prieur, L., Sempéré, R., Bianchi, M., Oubelkheir, K., and Bruyant, F.: Distribution of microbial biomass, production, respiration, dissolved organic carbon and factors controlling bacterial production across a geostrophic front (Almeria-Oran, SW Mediterranean Sea), Mar. Ecol. Prog. Ser., 269, 1-15, https://doi.org/10.3354/meps269001, 2004.

Vesanto, J., Alhoniemi, E., and Member, S.: Clustering of the SelfOrganizing Map, IEEE T. Neural Networ., 11, 586-600, 2000a.

Vesanto, J., Himberg, J., Alhoniemi, E., and Parhankangas, J.: SOM Toolbox for Matlab 5, (Report A57). Hensinki University of Technological, Espoo, Finland, 2000b.

Vidussi, F., Claustre, H., Manca, B. B., Luchetta, A., and Marty, J.C.: Phytoplankton pigment distribution in relation to upper thermocline circulation in the eastern Mediterranean Sea during winter, J. Geophys. Res., 106, 939-956, 2001.

Vilibić, I., Matijević, S., Šepić, J., and Kušpilić, G.: Changes in the Adriatic oceanographic properties induced by the Eastern Mediterranean Transient, Biogeosciences, 9, 2085-2097, https://doi.org/10.5194/bg-9-2085-2012, 2012.
Volpe, G., Colella, S., Brando, V. E., Forneris, V., La Padula, F., Di Cicco, A., Sammartino, M., Bracaglia, M., Artuso, F., and Santoleri, R.: Mediterranean ocean colour Level 3 operational multi-sensor processing, Ocean Sci., 15, 127-146, https://doi.org/10.5194/os-15-127-2019, 2019.

Wang, X. T., Cohen, A. L., Luu, V., Ren, H., Su, Z., Haug, G. H., and Sigman, D. M.: Natural forcing of the North Atlantic nitrogen cycle in the Anthropocene, P. Natl. Acad. Sci. USA, 201801049, https://doi.org/10.1073/pnas.1801049115, 2018.

Woodson, C. B. and Litvin, S. Y.: Ocean fronts drive marine fishery production and biogeochemical cycling, P. Natl. Acad. Sci. USA, 112, 1710-1715, https://doi.org/10.1073/pnas.1417143112, 2014.

Zairi, M. and Rouis, M. J.: Impacts environnementaux du stockage du phosphogypse à Sfax (Tunisie), Bull. des Lab. des ponts chaussées, 219, 29-40, 1999.

Zalidis, G., Stamatiadis, S., Takavakoglou, V., Eskridge, K., and Misopolinos, N.: Impacts of agricultural practices on soil and water quality in the Mediterranean region and proposed assessment methodology, Agric. Ecosyst. Environ., 88, 137-146, https://doi.org/10.1016/S0167-8809(01)00249-3, 2002.

Zoppini, A., Pettine, M., Totti, C., Puddu, A., Artegiani, A., and Pagnotta, R.: Nutrients, standing crop and primary production in western coastal waters of the adriatic sea, Estuar. Coast. Shelf S., 41, 493-513, https://doi.org/10.1016/0272-7714(95)90024-1, 1995. 